This is the final peer-reviewed accepted manuscript of

Cantonati, Marco; Segadelli, Stefano; OGATA, KEI; Tran, Ha; Sanders, Diethard; Gerecke, Reinhard; Rott, Eugen; FILIPPINI, MARIA; GARGINI, ALESSANDRO; Celico, Fulvio. A global review on ambient LimestonePrecipitating Springs (LPS): Hydrogeological setting, ecology, and conservation. SCIENCE OF THE TOTAL ENVIRONMENT 568. ISSN 0048-9697

DOI: $10.1016 /$ j.scitotenv.2016.02.105

The final published version is available online at:

http://dx.doi.org/10.1016/j.scitotenv.2016.02.105

Rights / License: The terms and conditions for the reuse of this version of the manuscript are specified in the publishing policy. For all terms of use and more information see the publisher's website.

This item was downloaded from IRIS Università di Bologna (https://cris.unibo.it/)

When citing, please refer to the published version. 


\title{
A global review on ambient Limestone-Precipitating Springs (LPS): Hydrogeological setting, ecology, and conservation
}

\author{
Eugen Rott ${ }^{\mathrm{f}}$, Maria Filippini ${ }^{\mathrm{g}}$, Alessandro Gargini ${ }^{\mathrm{g}}$, Fulvio Celico ${ }^{\mathrm{d}}$ \\ a Museo delle Scienze - MUSE, Limnology and Phycology Section, Corso del Lavoro e della Scienza 3, I-38123 Trento, Italy \\ ${ }^{\mathrm{b}}$ Emilia-Romagna Region, Geological Seismic \& Soil Survey, Bologna, Italy \\ c University of Innsbruck, Faculty of Geo- and Atmospheric Sciences, Institute of Geology, Innrain 52f, A-6020 Innsbruck, Austria \\ ' University of Parma, Dept. Physics \& Earth Sciences, Parma, Italy \\ e University of Tübingen, Institute of Evolution and Ecology, Tübingen, Germany \\ ${ }^{\mathrm{f}}$ University of Innsbruck, Faculty of Biology, Institute of Botany, Sternwartestrasse 15, Innsbruck A-6020, Austria \\ ${ }^{g}$ Alma Mater Studiorum University of Bologna, Dept. Biological, Geological E' Environmental Sciences - BiGeA, Bologna, Italy
}

Marco Cantonati a,*, Stefano Segadelli ${ }^{\mathrm{b}, \mathrm{d}}$, Kei Ogata ${ }^{\mathrm{d}}$, Ha Tran ${ }^{\mathrm{c}}$, Diethard Sanders ${ }^{\mathrm{c}}$, Reinhard Gerecke ${ }^{\mathrm{e}}$,

\section{H I G H L I G H T S}

- Limestone Precipitating Springs (LPS) are ideal to study biocalcification.

- Spring habitat protection is limited globally; in Europe there is a focus on LPS.

- We present a conceptual model to pre dict LPS occurrence to meet EU direc tives.

- Main impacts on LPS are water over draft and lacking appreciation of their relevance.

- LPS should be a flagship to achieve widespread conservation of springs in general.
G R A P H I C A L A B S T R A C T

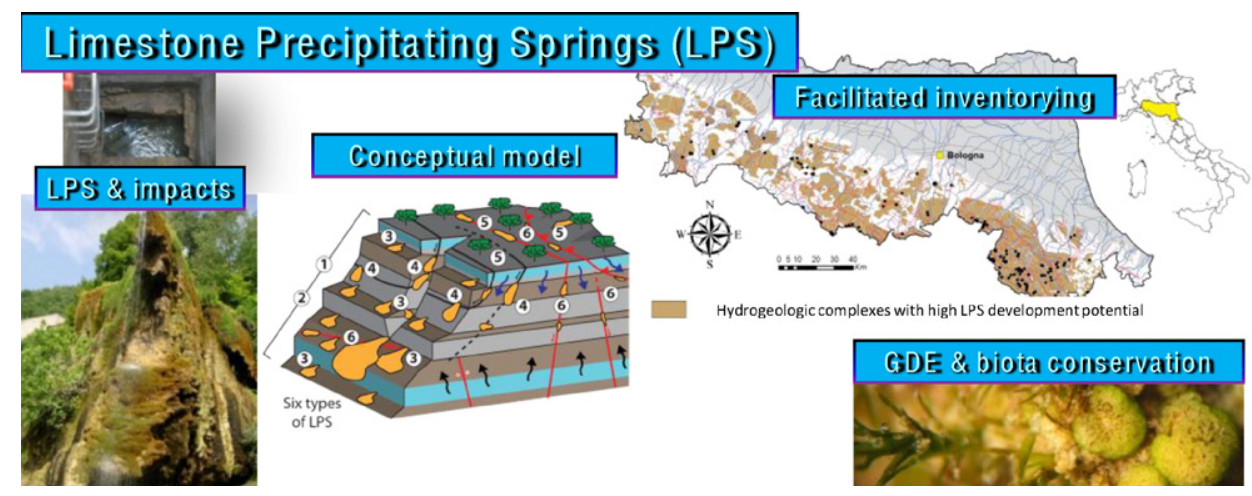

\section{A R T I C L E I N F O}

Keywords:

Limestone-Precipitating Springs

(LPS) Spring habitats

Biocalcification

EU Habitat Directive

Tufa Springs

Spring-Associated Limestones (SAL)

Freshwater conservation Travertines

\section{A B S T R A C T}

Springs are biodiversity hotspots and unique habitats that are threatened, especially by water overdraft. Here we review knowledge on ambient temperature (non geothermal) freshwater springs that achieve sufficient over saturation for $\mathrm{CaCO}_{3}$ by physical $\mathrm{CO}_{2}$ degassing and activity of photoautotrophs to deposit limestone, locally resulting in scenic carbonate structures: Limestone Precipitating Springs (LPS). The most characteristic organisms in these springs are those that contribute to carbonate precipitation, e.g.: the mosses Palustriella and Eucladium, the crenophilous desmid Oocardium stratum, and cyanobacteria (e.g., Rivularia). These organisms ap pear to be sensitive to phosphorus pollution. Invertebrate diversity is modest, and highest in pools with an aquatic terrestrial interface. Internationally, comprehensive legislation for spring protection is still relatively scarce. Where available, it covers all spring types. The situation in Europe is peculiar: the only widespread spring type included in the EU Habitat Directive is LPS, mainly because of landscape aesthetics. To support LPS inventorying and management to meet conservation legislation requirements we developed a general conceptu al model to predict where LPS are more likely to occur. The model is based on the pre requisites for LPS: an aqui fer lithology that enables build up of high bicarbonate and $\mathrm{Ca}^{2+}$ to sustain $\mathrm{CaCO}_{3}$ oversaturation after spring emergence, combined with intense groundwater percolation especially along structural discontinuities

\footnotetext{
* Corresponding author.

E-mail address: marco.cantonati@muse.it (M. Cantonati).
} 
(e.g., fault zones, joints, schistosity), and a proper hydrogeological structure of the discharging area. We validated this model by means of the LPS information system for the Emilia Romagna Region (northern Italy). The main threats to LPS are water diversion, nutrient enrichment, and lack of awareness by non specialized persons and administrators. We discuss an emblematic case study to provide management suggestions. The present review is devoted to LPS but the output of intense ecological research in Central Europe during the past decades has clearly shown that effective conservation legislation should be urgently extended to comprise all types of spring habitats.

\section{Introduction: What are Limestone-Precipitating Springs (LPS)?}

Springs may represent or feed valuable GDE (Groundwater Dependent Ecosystems; e.g., Kløve et al., 2011a, 2011b). Springs are unique habitats threatened by multiple impacts, either anthropo genic (water overdraft, e.g., Powell et al., 2015; contamination or drainage from subsurface excavations) or natural (e.g., the effects of climate change on the hydrologic cycle; Hartmann et al., 2014). One of the main reasons why springs are biodiversity hotspots (e.g., Cantonati et al., 2012a) is that they cover an extremely wide range of water chemistry, temperature, and environmental settings, and sustain a high within habitat patchiness.

Spring types have been classified on the basis of diverse indicators (Alfaro and Wallace, 1994; Kresic, 2010): hydrology (discharge rate, e.g., Meinzer, 1923; Netopil, 1971; recession coefficient, e.g., Gargini et al., 2008; active vs. inactive, Fensham et al., 2015), hydrogeology (e.g., Civita, 1973), geology and morphology (e.g., Springer and Stevens, 2009), physico chemistry (e.g., electrical conductivity, Total Dissolved Solids, e.g., Clarke, 1924), temperature (e.g., Glazier, 2009, with a transi tion between cool and thermal groundwater between 30 and $40{ }^{\circ} \mathrm{C}$ ), flow conditions at the spring head (Thienemann, 1924), and biological characteristics, in particular vegetation (bryophytes + vascular plants; e.g., Ellenberg, 2009) and invertebrate communities (e.g., Gerecke and Di Sabatino, 1996; Schröder et al., 2006; Martin and Brunke, 2012). Fur thermore, biota based spring types can be recognized by using benthic algae forming colourings and/or structures identifiable with the naked eye (Cantonati et al., 2012b), or their diatom microflora (Cantonati et al., 2012c). A comprehensive multi taxon classification by "Procrustes" analysis showed that each group of organisms provides useful specific spring characters that however are related to other groups only at the level of broad ecological categories (e.g., photoautotrophs, meiofauna etc.; Spitale et al., 2012). In the USA, twelve spring types were distin guished by geomorphology and recurring species (Springer and Stevens, 2009).

Virtually all groundwater is subject to some amount of geothermal heating but this may be very small or negligible in the case of shallow, subsurface, very short recharge discharge systems. When significant geothermal groundwater heating can be excluded, spring water will be near the mean annual air temperature (MAAT) of the recharge area (cf. Pentecost, 2005), and it was recommended that these be renamed 'ambient springs' (e.g., Glazier, 2009).

There is no universally accepted temperature limit for spring water to be designated as thermal, i.e., water that was substantially heated by geothermal energy. In Europe, a temperature of $20{ }^{\circ} \mathrm{C}$ at spring emer gence is generally accepted (e.g., Boch et al., 2005). Other limits to ther mal water have been proposed such as, for instance, 36.7 ${ }^{\circ} \mathrm{C}$ (mean core temperature of humans; Pentecost et al., 2003) and $21.1^{\circ} \mathrm{C}\left(70^{\circ} \mathrm{F}\right)$.

Over most of the Earth, the mean annual air temperature near ground is $<20^{\circ} \mathrm{C}$ (see, e.g., the Köppen modified scheme of world cli mates). In some areas located in the subtropical high pressure cells, and over most of tropical lowlands, however, mean annual air temper ature is above $20{ }^{\circ} \mathrm{C}$; in consequence, there, ambient temperature springs can also be warmer than $20^{\circ} \mathrm{C}$ (e.g., Carthew et al., 2006). There fore, we avoid the terms 'cool' and 'hot' or 'warm' to designate spring water temperature, but prefer to speak of 'ambient' temperature springs that are dealt with herein.
With respect to limestone deposition from springs, the temperature of the water at emergence was used for classification. Limestones de posited from thermal springs are commonly termed "travertine", whereas limestones of 'cool' (non thermal) springs are generally classi fied as tufa or calcareous tufa (e.g., Pentecost, 2005; Golubić et al., 2008). Both these terms, however, are problematic because they comprise an a priori interpretation of spring water temperature (which may be diffi cult to deduce for fossil systems), and of the position of a given lime stone within a spring depositional system (in fossil deposits, and even for parts of active spring limestone deposystems, this may give rise to misinterpretations; see discussion in Sanders et al., 2011). The term tufa also cannot be reserved for highly porous (>10 15\% porosity; see Ford and Pedley, 1996; Pedley, 2009) limestones from 'cool' springs, be cause similarly high porosities are observed in actively forming traver tines of thermal springs. To avoid these confusions, we designate the deposits of Limestone Precipitating Spring (LPS) neutrally as spring associated limestones (SAL), irrespective of actual or interpreted water temperature, of derivation of spring waters (meteogene or thermogene), and irrespective of porosity (Sanders et al., 2011; Cantonati et al., 2012b, 2012c).

In general, composition and polymorphism of spring related minerals are controlled by water chemistry rather than by the microbial communities mediating precipitation (Konhauser, 2007). Most SAL deposits consist of low magnesian calcite (Table 1 ). This reflects the most widespread chemical composition of LPS, i.e., $\mathrm{Ca}^{2+} \mathrm{HCO}_{3}^{-}$ waters with smaller amounts of other common ions (mainly sulphate, chloride, $\mathrm{Mg}, \mathrm{Na}, \mathrm{K}$, and dissolved silica). Ambient temperature LPS with a $\mathrm{Mg} / \mathrm{Ca}$ molar ratio $\geq 2.53$ are comparatively rare; these are characterized by precipitation of magnesian calcite and aragonite (Table 1 ). The precipitation of low magnesian calcite is further impeded or modified by elevated concentrations of sulphate, orthophosphate, and some groups of organic substances (e.g., Bischoff and Fyfe, 1968; House, 1987; Plant and House, 2002; Lin et al., 2005; Fernández Díaz et al., 2010). The impact of any of these compounds on crystal growth, however, seems to depend on many factors (e.g., concentration, $\mathrm{pH}$, association with other ions or molecules), and details are far from resolved. In dysoxic to anox ic LPS, if present even in very low concentrations, $\mathrm{Fe}^{2+}$ completely blocks $\mathrm{CaCO}_{3}$ precipitation (cf. Dromgoole and Walter, 1990). At spring emergence, thus, first the $\mathrm{Fe}^{2+}$ has to be removed by iron bacterial oxidation (e.g., Gallionella, Leptothrix) into virtually insoluble $\mathrm{Fe}^{3+}$ hydroxides (e.g., Søgaard et al., 2001; Chan et al., 2009). Only when the $\mathrm{Fe}^{2+}$ is exhausted, farther downstream, $\mathrm{CaCO}_{3}$ precipitation can start, resulting in 'mineralogically zoned' iron oxide $/ \mathrm{CaCO}_{3}$ deposits (Sanders et al., 2011).

The crystal habit of pristine LMC precipitates (pristine = crystal pre cipitated from and still bathed in its parent solution) is extremely vari able and ranges, for instance, from perfect ditrigonal scalenohedra to crystal skeletons to spheroids to needles, to name a few; similarly, crys tal size ranges from nanometer to millimeter scale (see, e.g., Freytet and Verrecchia, 1998; Pentecost, 2005; Turner and Jones, 2005; Shiraishi et al., 2008). Whereas some correlation of crystal habit with water chemistry is obvious (see above), further influences most proba bly are degree of oversaturation and turbulence at microhabitat, rate of nucleation of crystals or subcrystals, fluctuations of water chemistry or water supply and, finally, biological mediation of precipitation. 
Table 1

Mineralogy and polymorphy of most common $\mathrm{CaCO}_{3}$ minerals formed from ambient-temperature springs.

\begin{tabular}{|c|c|c|c|}
\hline $\begin{array}{l}\text { Mineral; composition; } \\
\text { crystal system }\end{array}$ & Chemical controls & Geological controls & Remarks \\
\hline Low-magnesian calcite; & $\begin{array}{l}\text { Precipitates from } \mathrm{Ca}^{2+}-\mathrm{HCO}_{3} \text { waters low in } \\
\mathrm{Mg}^{2+} \text { (common for LPS) }\end{array}$ & Rocks and/or sediments rich in Ca; & Most common mineral from LPS. \\
\hline $\begin{array}{l}\mathrm{CaCO}_{3} \text { with }<4 \mathrm{~mol} \% \mathrm{MgCO}_{3} ; \\
\text { trigonal }\end{array}$ & & $\begin{array}{l}\text { source of } \mathrm{HCO}_{3} \text { : dissolution of rock or } \\
\text { sediment, soil cover, hypogenic } \mathrm{CO}_{2} \text { ascend }\end{array}$ & $\begin{array}{l}\text { Takes many crystal habits from rhombs } \\
\text { to fibers }\end{array}$ \\
\hline $\begin{array}{l}\text { Magnesian calcite; } \\
\mathrm{CaCO}_{3} \text { with }>4 \text { mol} \% \mathrm{MgCO}_{3} \text {; } \\
\text { trigonal }\end{array}$ & $\begin{array}{l}\text { Forms from waters with } \mathrm{Mg} / \mathrm{Ca} \text { molar ratio } \\
\text { above c. } 2.5-3 \text { (rare for LPS) }\end{array}$ & $\begin{array}{l}\text { As above, but with Mg source, } \\
\text { e.g., mafic-ultramafic rocks, magnesite } \\
\text { deposits, or Mg-rich gangue of deposits }\end{array}$ & $\begin{array}{l}\text { Rare mineral from } \\
\text { ambient-temperature LPS. } \\
\text { Typically in fibrous crystals that form } \\
\text { fringes and botryoids }\end{array}$ \\
\hline $\begin{array}{l}\text { Aragonite; } \\
\mathrm{CaCO}_{3} \text { with }<4 \text { mol\% } \mathrm{MgCO}_{3} \text {; } \\
\text { orthorhombic polymorph of } \\
\mathrm{CaCO}_{3}\end{array}$ & $\begin{array}{l}\text { Forms from waters with } \mathrm{Mg} / \mathrm{Ca} \text { molar ratio } \\
\text { above c. } 2.5-3 \text {, and/or from waters with high } \\
\mathrm{HCO}_{3} \text { concentration (rare for LPS) }\end{array}$ & As above for magnesian calcite & $\begin{array}{l}\text { Rare mineral from } \\
\text { ambient-temperature LPS. Common in } \\
\text { hot-spring limestones (not treated } \\
\text { herein). } \\
\text { Typically in fibrous crystals forming } \\
\text { fringes and botryoids }\end{array}$ \\
\hline
\end{tabular}

Besides thermal/geochemical/mineralogical characteristics, other aspects of LPS are locally important around the world, e.g. the cultural, environmental, and societal significance of LPS. For instance, in Germany, a small LPS, deposited a large SAL over several thousands of years, known as the largest 'channel on a stone ridge' (Ger. Steinerne Rinne) in Germany ( $40 \mathrm{~m}$ long and $5 \mathrm{~m}$ high). The 'Growing Rock' (Ger. Wachsender Stein) of Usterling, also known as Johannes Rock after John the Baptist, is a natural monument in Usterling (Landau, Bavaria). Its oldest representation can be found on a late Gothic altar in the village church of St. John of Usterling: In one image, Christ's baptism by John is relocated to this growing rock a cultural history curiosity. The illustration shows the natural monument as it should have looked in the 1500s. In 2006 it was admitted to the list of excellent National Geotopes of Germany. Over the rock stands St. John's Chapel, and at its foot a chapel shrine with a wooden Johannes figure (Bauer et al., 2009). In Section 6 we discuss and even more striking example in Italy (Labante), where a scenic LPS is still active in spite of multiple impacts, it includes impressive fossil SAL extensively used since antiquity (Etruscans), and it is an emblematic example of the development of environ mental policies on LPS in the last decades.

This review paper summarizes knowledge on freshwater, ambient temperature LPS and their biota, on LPS distribution and conservation status worldwide, and on major impact types (e.g., water overdraft, P enrichment, lack of awareness) while providing management sugges tions. At the same time the review paper presents a novel conceptual model to predict LPS occurrence from environmental settings, validated by its application to worldwide case studies (own + literature) and discussed illustrating a regional application. One emblematic case study will exemplify the main impact types.

\section{Biota and biocalcification}

Characteristic and common taxa of the flora and fauna found in LPS are summarized in Table 2, with indication of the microhabitat(s) they typically occupy within LPS systems, and shown in Fig. 1. Whereas ele ments of the flora can contribute to shape limestone deposition in springs, elements of the fauna of LPS are frequently hindered in their life functions by limestone deposition.

\subsection{Flora}

Besides the preponderant role of physical $\mathrm{CO}_{2}$ degassing by turbulence, pressure release, and temperature increase of waters from the spring origin to downstream that shifts water chemistry towards

oversaturation for $\mathrm{CaCO}_{3}$ (Merz Preiß and Riding, 1999; Chen et al., 2004), active biogenic processes can lead to deposition of low magnesian calcite by photosynthetic withdrawal of $\mathrm{HCO}_{3}^{-}$and $\mathrm{CO}_{2}$ (Schagerl and Wukovits, 2014). In addition, passive trapping and binding of particles and enrichment of $\mathrm{HCO}_{3}^{-}$and $\mathrm{Ca}^{2+}$ on organic surfaces (polysaccharides or proteins) can take place (e.g., Merz Preiß and Riding, 1999; Kawaguchi and Decho, 2002; Turner and Jones, 2005; Dittrich and Sibler, 2010). Downstream changes in oversaturation related to photosynthesis within spring streams may amount to a few percent only (Pentecost, 1992, 2005; Shiraishi et al., 2008), except for situations where Rivularia dominates and/or in larger spring fed streams (e.g., Rott et al., 2000) where no inorganic limestone precipitation takes place (Shiraishi et al., 2008).

Several phylogenetic lines among oxygenic photoautotrophs are supposed to contribute to biocalcification processes in LPS, including cyanobacteria, eucaryotic algae, and bryophytes (Fig. 1a i).

Bryophytes (Fig. 1a e) are the most characteristic organisms that contribute probably to a larger extent to carbonate precipitation in springs, and to the formation of pools and cascades by $\mathrm{CO}_{2}$ consumption in photosynthesis; this holds in particular for widespread (circumpolar and warm temperate) mosses, such as Eucladium verticillatum and Palustriella spp. (Cratoneurion commutati in Europe, Dierssen, 2001; Tomaselli et al., 2011; Palustriella falcata and Cratoneurion filicinum in America, Flora of North America Editorial Committee eds., 1993+).

A specific eukaryotic alga potentially confined to LPS is the desmid (green alga) Oocardium stratum (Fig. 1a b) Sanders and Rott, 2009; Rott et al., 2012; Linhart and Schagerl, 2015), which shows an almost worldwide distribution (at least circumpolar, temperate, and tropical); it is documented for China, Cuba, India, North America, and a few loca tions all over Europe (see summary in Linhart and Schagerl, 2015).

Cyanobacteria are found widespread in both freshwater and marine carbonate depositional environments often related to aquatic in transition to terrestrial habitats (stones, soils). Rivularia is one of the most interesting in relation to LPS (Fig. $1 \mathrm{~g}$ i). This genus is represented in freshwater and marine habitats (Freytet and Verrecchia, 1998).

Diatoms (Fig. 1f) are seasonally abundant in LPS, mainly during the cold and low illuminated season (e.g., Sanders and Rott, 2009; Linhart and Schagerl, 2015). Gomphonema calcareum, in spite of its specific eithet, is usually not observed to form carbonate encrusted colonies (Levkov et al., 2016). Other Gomphonema species are much more com mon in LPS (cf. Table 2), in particular Gomphonema lateripunctatum, an indicator species of the spring type 'carbonate hygropetric springs (= rock face seepages) and LPS' (Cantonati et al., 2012c). Macroscopic col onies of the hard water diatom species Cymbella excisiformis were 
Table 2

Biota involved in the formation of LPS and dependent or associated with LPS ecological niches.

\begin{tabular}{|c|c|c|}
\hline Taxon & LPS formation & $\begin{array}{l}\text { LPS-associated } \\
\text { ecological niches }\end{array}$ \\
\hline \multicolumn{3}{|l|}{ PHOTOAUTOTROPHS } \\
\hline \multicolumn{3}{|l|}{ Cyanobacteria } \\
\hline Rivularia spp. & $\mathrm{x}$ & \\
\hline Homoethrix crustacea & $\mathrm{x}$ & \\
\hline Phormidium incrustatum & $\mathrm{x}$ & \\
\hline Tolypothrix sp. & $\mathrm{x}$ & \\
\hline Scytonema (Myochrotes) spp. & & Hy \\
\hline \multicolumn{3}{|l|}{ Diatoms } \\
\hline Achnanthes trinodis & Eu-LPS & Hy \\
\hline Brachysira calcicola & Eu-LPS & \\
\hline Gomphonema lateripunctatum & & Hy \\
\hline Fragilaria distans & Eu-LPS & \\
\hline Delicata minuta & Eu-LPS & Hy \\
\hline Denticula elegans & Eu-LPS & $\mathrm{Hy}$ \\
\hline Cymbella diminuta & Eu-LPS & \\
\hline $\begin{array}{l}\text { Cymbella excisiformis } \\
\text { (macroscopic colonies) }\end{array}$ & & Ls \\
\hline \multicolumn{3}{|l|}{ Desmidiacean green algae } \\
\hline Oocardium stratum & $\mathrm{x}$ & \\
\hline \multicolumn{3}{|l|}{ Yellow-green algae } \\
\hline Vaucheria sp. & $\mathrm{x}$ & \\
\hline \multicolumn{3}{|l|}{ Mosses } \\
\hline Palustriella commutata & $\mathrm{x}$ & \\
\hline Eucladium verticillatum & $\mathrm{x}$ & \\
\hline Cratoneurion filicinum & $\mathrm{x}$ & \\
\hline \multicolumn{3}{|l|}{ Vascular plants (Brassicaceae) } \\
\hline Cochlearia bavarica & & $\mathrm{Br}$ \\
\hline \multicolumn{3}{|l|}{ INVERTEBRATES } \\
\hline \multicolumn{3}{|l|}{ Caddisflies } \\
\hline \multicolumn{2}{|l|}{ Rhyacophila pubescens } & Ls \\
\hline \multicolumn{3}{|l|}{ Moth flies (Diptera Psychodidae) } \\
\hline \multicolumn{2}{|l|}{ Pericoma trifasciata gr. } & Eu-LPS, Hy \\
\hline \multicolumn{3}{|l|}{ Midges (Diptera Chironomidae) } \\
\hline \multicolumn{2}{|l|}{ Tanytarsus emarginatus } & Ls \\
\hline \multicolumn{2}{|l|}{ Rheotanytarsus reissi } & Ls \\
\hline \multicolumn{3}{|l|}{$\begin{array}{l}\text { Gammarids (Crustacea, } \\
\text { Amphipoda, Gammaridae) }\end{array}$} \\
\hline \multicolumn{2}{|l|}{ Gammarus fossarum } & Eu-LPS, Lc, Ls \\
\hline \multicolumn{3}{|c|}{ Salamanders (Caudata, Salamandridae) } \\
\hline Salamandra salamandra & & Lc \\
\hline
\end{tabular}

Eu-LPS = Eucrenal of LPS, Lc = Limnocrenic, $\mathrm{Hy}=$ Hygropetric, $\mathrm{Ls}=$ Lotic sectors, $\mathrm{Br}=$ Bryophytes \& fine-grained sediments.

observed in a LPS, however not encrusted with calcium carbonate (MC unpublished data).

Bryophytes may calcify directly on their surface so that dead organic parts (e.g., stems) remain enclosed in the calcites and degrade gradually (Fig. 1e); in many cases, additional calcification of organisms living on the bryophyte plants, such as diatoms or Oocardium stratum plays a considerable role providing a large surface for smaller biota. Eucaryotic microalgae, such as Oocardium stratum, can precipitate low magnesian calcite at vertical accumulation rates of up to $10 \mathrm{~mm} \mathrm{y}^{-1}$ (Sanders and Rott, 2009); this alga seems to grow only in waters conducive to low magnesian calcite precipitation (Rott et al., 2012). The initial calcification of 0 . stratum is highly variable with respect to basal crystallisate fabrics, so that several (at least three major within a cross section of the Alps and within the spring variability) of most probably biotic induced calcification types (calcites) were related to environmental variations in space and time of microhabitat conditions (e.g., $\mathrm{pH}$, temperature, $\mathrm{CO}_{2}$ oversatura tion; Rott et al., 2012). Several cyanobacterial taxa show indeterminate calcification fabrics found also in LPS, although the precise mechanisms of cyanobacterial calcification are not yet clarified in detail (see e.g., Merz, 1992; Freytet and Verrecchia, 1998; Shiraishi et al., 2008). An interesting example of specific cyanobacterial calcites is known from the genus Rivularia (Fig. $1 \mathrm{~h}$ i) with a specific carbonate microfabric identifiable as of cyanobacterial origin (e.g., Flügel, 2004). Rivularia often forms primarily concentric layers within their young hemispheric colonies with calcite rhombs of micro to orthospar size embedded in the mucilage layers be tween filament sheaths until finally the trichomes are completely fixed in calcite spar (Obenlüneschloss, 1991). Whereas early calcification is influenced by oversaturation for $\mathrm{CaCO}_{3}$, along spring streams other fac tors such as local current velocity and turbulence similarly are impor tant (e.g., Freytet and Verrecchia, 1998; Sanders and Rott, 2009; Gradzinski, 2010).

Diatoms commonly are considered as non influential with respect to spring calcification (Fig. 1f), yet they appear to contribute by inducing the formation mainly of loose, micritic to sparitic calcium carbonate sediment not firmly bound into specific calcification fabrics (Sanders and Rott, 2009). Detailed microscopic and SEM studies show that dia tom frustules associated with $\mathrm{CaCO}_{3}$ are widespread. In the mucilage of diatom mats, calcite crystals of micro to orthospar size are common. In addition, diatom frustules and also their stalks are frequently embed ded in calcite crystals, and loose aggregates of frustules embedded in clumps of micrite to microsparite are common (Wallner, 1935; Sanders and Rott, 2009). Whether the diatom frustules and their stalks are just passively trapped within the crystals or crystal clusters, or to what extent they took an active role in inducing $\mathrm{CaCO}_{3}$ precipitation, however, is unknown. In mid latitudes with a distinct climatic seasonal ity, the seasonal changes of spring biota associated with changes of water chemistry, temperature and illumination typically impart annual or seasonal laminations to SAL deposits (e.g., Kano et al., 2003; Kawai et al., 2006; Shiraishi et al., 2008; Sanders and Rott, 2009; Arenas et al., 2010).

\subsection{Fauna}

LPS typically show low faunal diversity. Most animals adapted to this habitat live in pool areas below cascades or in the aquatic terrestrial interface where allochthonous organic matter accumulates (Table 2). The proportion of specialized spring dwellers is low, and the fauna of LPS is very poor in character species (Zollhöfer, 1997; Martin and Wischniowsky, 2014). In general, faunal richness in springs is found to be directly influenced by microhabitat diversity, in particular by the availability of stable transition habitats in the aquatic terrestrial eco tone. Since the limestone cover produced by $\mathrm{CaCO}_{3}$ deposition imparts homogenization of microstructures and reduction of microhabitat rich ness, a low animal diversity is typical for LPS (Dürrenfeldt, 1978; Martin and Wischniowsky, 2014).

Animal species able to persist in the petrified channels are mostly rithrobiontic generalists which migrate from their preferred habitat (mountain streams) into spring brooks (in lotic sectors: gammarids, in pools: salamander larvae and some taxa of Trichoptera).

An exception is the case less larva of the caddisfly Rhyacophila pubescens, which can be considered an outstanding element of LPS in Europe. It is strictly bound to springs and low order stream sectors rich in calcium carbonate deposits. A genetic analysis showed a rather high isolation of local populations, probably due to habitat fragmentation combined with a low dispersal rate of adults (Engelhardt et al., 2011). With regard to other genera and families, the trichopteran fauna, usually very diversified in springs, is uniform and poor in LPS. Kühn (1940) reports an extreme example of case building caddisflies literally "caught" and immobilized by quickly growing calcium carbonate crusts. Most probably, the involved specimens were at a late nymphal stage, at the beginning of pupal quiescence.

Two phenomena observed among Diptera larvae may be mentioned in this context: At oversaturation for $\mathrm{CaCO}_{3}$, larvae of Pericoma species (Psychodidae) tend to become encrusted by calcium carbonate 

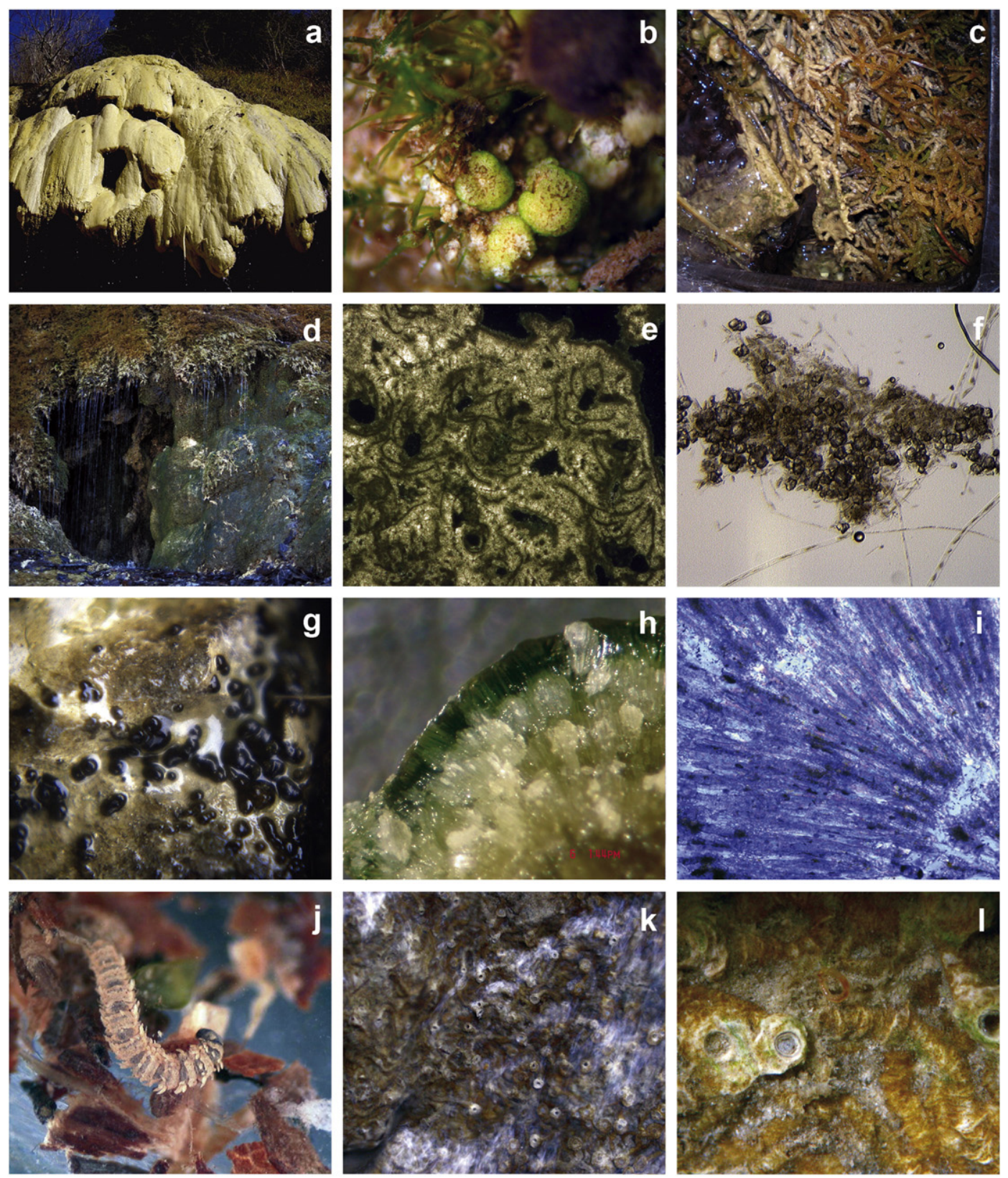

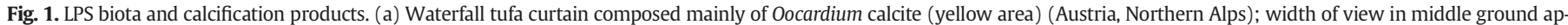

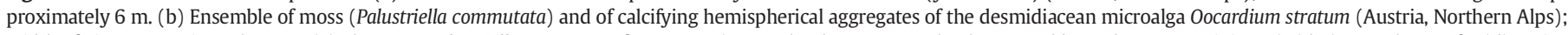

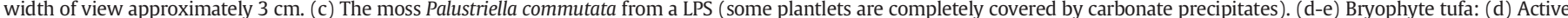

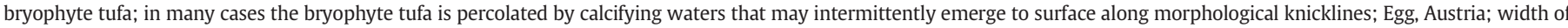

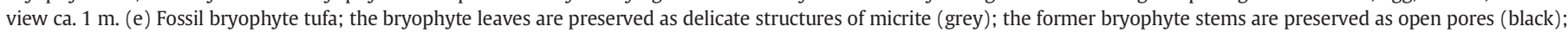

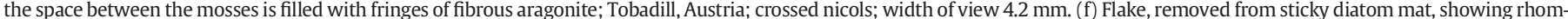

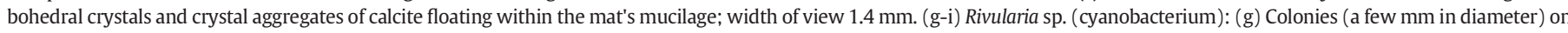

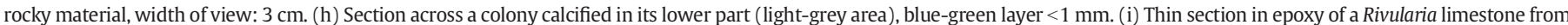

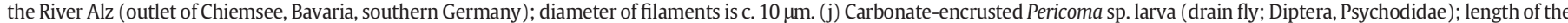

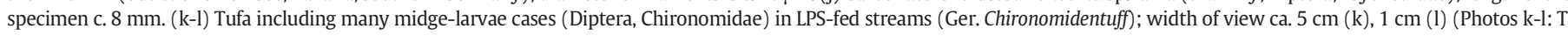
Ekrem).

(Feuerborn, 1923; Vaillant and Withers, 1993). The $\mathrm{CaCO}_{3}$ precipitates preferably around the long dorsal setae which take the appearance of horn like appendages, but also on other integument structures (Fig. $1 \mathrm{j}$ ). The animals are obviously not hampered in their lifestyle, and even have advantages such as mechanical body protection and camouflage. Larvae of the non biting midges (Chironomidae) Tanytarsus emarginatus and Rheotanytarsus reissi normally live in selfproduced silk tubes covered by fine sand. In springs and streams with rapid $\mathrm{CaCO}_{3}$ precipitation they form dense populations associated with Fissidens spp. moss and cyanobacteria of the genus Rivularia in biohermal structures. This so called "chironomid tufa" (Fig. 1k 1) grows passively without active contribution to $\mathrm{CaCO}_{3}$ precipitation by the dwelling animals. The abundance of such populations, however, suggests that they profit from this lifestyle (Thienemann, 1934; Kühn, 1940; Burmeister and Reiss, 2003).

As a general rule, decreased faunal diversity correlates with rate of carbonate precipitation in LPS. In "moderate rate LPS", formation of riparian transition zones with organic debris and moss/ macrophyte 
vegetation may allow for the formation of pools with a typical crenobiontic fauna. In Central Europe, the water mite Lebertia helocrenica is a potential character species of such habitats. The species, however, is known from three sites only (in the Southern and Northern Alps and Prealps; Gerecke, 2009); this highlights the need for more fau nistic research dedicated to "moderate rate LPS".

\section{Worldwide conservation status of Limestone-Precipitating Springs}

In Europe, the conservation legislation of LPS is based on the Annex I of the Habitat Directive (EU HD, 1992) in which LPS are listed as "Petri fying springs with tufa formation (Cratoneurion)" (EU Code 7220). Among spring habitats mentioned in the Habitat Directive, LPS are by far the most widespread. However, for the sake of completeness, we note that the Habitat Directive Annex I includes also two very special and geographically localized types of springs: "Inland salt meadows" (Puccinellietalia distantis, EU Code 1340, including some inland saline springs), and "Fennoscandian mineral rich springs and spring fens" (EU Code 7160).

Inclusion in the Habitat Directive allows designated LPS to be preserved in the frame of the Natura 2000 coordinated network of protected areas. Furthermore, some LPS sites are protected as National Parks or UNESCO World Heritage sites, such as the Plitvice Lakes Nation al Park in Croatia.

In connection to LPS and spring protection, it might be also worth mentioning that downstream and in close proximity to SAL, "springs with iron precipitates" can occasionally be found in form of 'mineralogically zoned' iron oxide/calcium carbonate depositing streams. This relatively rare type of spring requires anoxic to dysoxic groundwater conditions, and is remarkable from a mineralogical and biological point of view (cf. Sanders et al., 2011).

On the basis of an international consultation from all continents (see Acknowledgements), it can be stated that the situation in Europe (i.e. spring protection focused on LPS) is very peculiar, and cannot be found anywhere else in the world. Internationally, comprehensive leg islation for the protection of spring habitats in general is still relatively rare. In countries where it is available, it covers all spring types, or broad categories of spring habitats (e.g., two categories are considered in Australia: Tertiary springs fed by localized aquifers, and Discharge springs fed by the Great Artesian Basin; Renee Rossini, University of Queensland, St. Lucia, Australia, personal comm.).

However, there are some interesting local situations that combine approaches, or partly differ from the situation as described above.

In Finland, there is no special legislation for LPS but the EU Habitat Directive applies. Interestingly, in addition, at the national level, Finland has the 'Water Act' which protects all pristine or close to pristine springs as habitats from damaging, and the 'Forest Act' which protects the forested marginal surroundings of all pristine/close to pristine springs from excess forestry (Jari Ilmonen, Biodiversity Re search Programme, Finnish Environment Institute, Helsinki, Finland, personal comm.).

The USA have no protection for LPS (Larry Stevens, MNA Springs Stewardship Institute, Flagstaff, AZ, personal comm.) but there is a very peculiar situation in the State of Minnesota that has undertaken a specific conservation step in favour of LPS.

In Minnesota, there is a state law and associated rules (Minnesota Statutes 103G.223 Calcareous Fens; Minnesota Rules Chapter 8420.0935 Standards and Criteria for Identification, Protection, and Management of Calcareous Fens) aimed specifically at protecting what are defined as calcareous fens, which are peat accumulating wetland areas supported by upwelling calcium/magnesium carbonate rich groundwater, often having carbonate precipitates (tufa or marl). This law does not apply to other types of springs, nor are there any other regulations specifically focused on springs (Doug Norris, Wetlands Program Coordinator,
Minnesota Dept. of Natural Resources, Division of Ecological and Water Resources, St. Paul, MN, USA, personal comm.).

At worldwide scale water has since long been treated as an economic good. The "sanitary revolution" of the 19th century saw the demand for public ownership and management. This determined an emphasis on the public good nature of water and led to the development of strongly subsidized public systems. In the late 1980s, however, there was diffuse "privatization" of public services with all related problems of setting tariffs and prices (Rogers et al., 2002). As a consequence, springs are even more threatened since disregarded as natural habitats, with a strong tendency to consider them exclusively as a source of pri marily (economically) precious water resources.

As other freshwater environments, LPS are also threatened by nutri ent enrichment. Recent findings of Oocardium stratum in 8 springs and spring complexes within a N S transect across the Alps were mostly from sites with low $\mathrm{TP}\left(<10 \mu \mathrm{g} \mathrm{L}^{-1}\right)$ but variable nitrate concentrations ( $>2000 \mu \mathrm{g} \mathrm{L}^{-1}$ in 3 out of 5 sites). This could be an indication that this biocalcifier is impeded by excess phosphates (House, 1987; Rott et al., 2012).

\section{A conceptual model on ambient-temperature Limestone-Precipitating Springs distribution}

Based on direct observations and revision of available published and unpublished datasets, we here present a conceptual model on the formation of LPS, with a focus on geological structure. The main aim of this model is to highlight how the structural stratigraphic framework controls the hydrologic system in creating compartments, baffles, barriers and preferential groundwater flow pathways. In this framework, the proposed classification specifically provides insights on the subsurface structural architecture and physiography of the geological setting, which have been often overlooked in the concerning literature so far, and thus intended to integrate and complement the other widely used classifications based on different approaches considering the surface expressions of such deposits (see e.g. Pedley, 1990; Ford and Pedley, 1996; Pentecost, 2005; Pedley, 2009; Jones and Renaut, 2010).

Our database also includes those comparatively rare situations in which carbon dioxide is not derived from the atmosphere and/or the soil cover (e.g., Celico et al., 2010), but from deep sources related to hypogenic processes such as anaerobic degradation of hydrocarbons (e.g., Chakraborty and Coates, 2004) and metamorphism of carbonate rocks (e.g., Glassley, 1983; Ague, 2000; Bissig et al., 2006). We however exclude those cases in which "warm" water (compared to the environ mental temperature; see above) is involved, and in which $\mathrm{CO}_{2}$ deriva tion is directly related to magmatic and hydrothermal processes.

\subsection{LPS structural background: types and significance}

The model proposed focuses on structural heterogeneities and the related distribution of groundwater flow paths, assuming favourable bi ological, physical, and chemical conditions for LPS formation at the sur face, already described in the classically used schemes deposits (see e.g. Pedley, 1990; Ford and Pedley, 1996; Pentecost, 2005; Pedley, 2009; Jones and Renaut, 2010). The model encompasses six (6) LPS types (Fig. 2) representing different associations of interacting and overlap ping processes and products.

Type 1 LPS develops from well to partly consolidated lithologies, where the aquifer is defined by primary (e.g., depositional) and second ary (e.g., diagenetic) matrix permeability due to porosity (e.g., Becker and Shapiro, 2000). The groundwater flow is funnelled and/or vertically compartmentalized. Eventual emergence as an LPS is mainly controlled by depositional diagenetic discontinuities (e.g., stratigraphic surfaces, diagenetic fronts; Mayo et al., 2003).

Type 2 LPS encompasses situations where the contribution from the matrix is negligible, and the overall bulk permeability of the hydrologic 


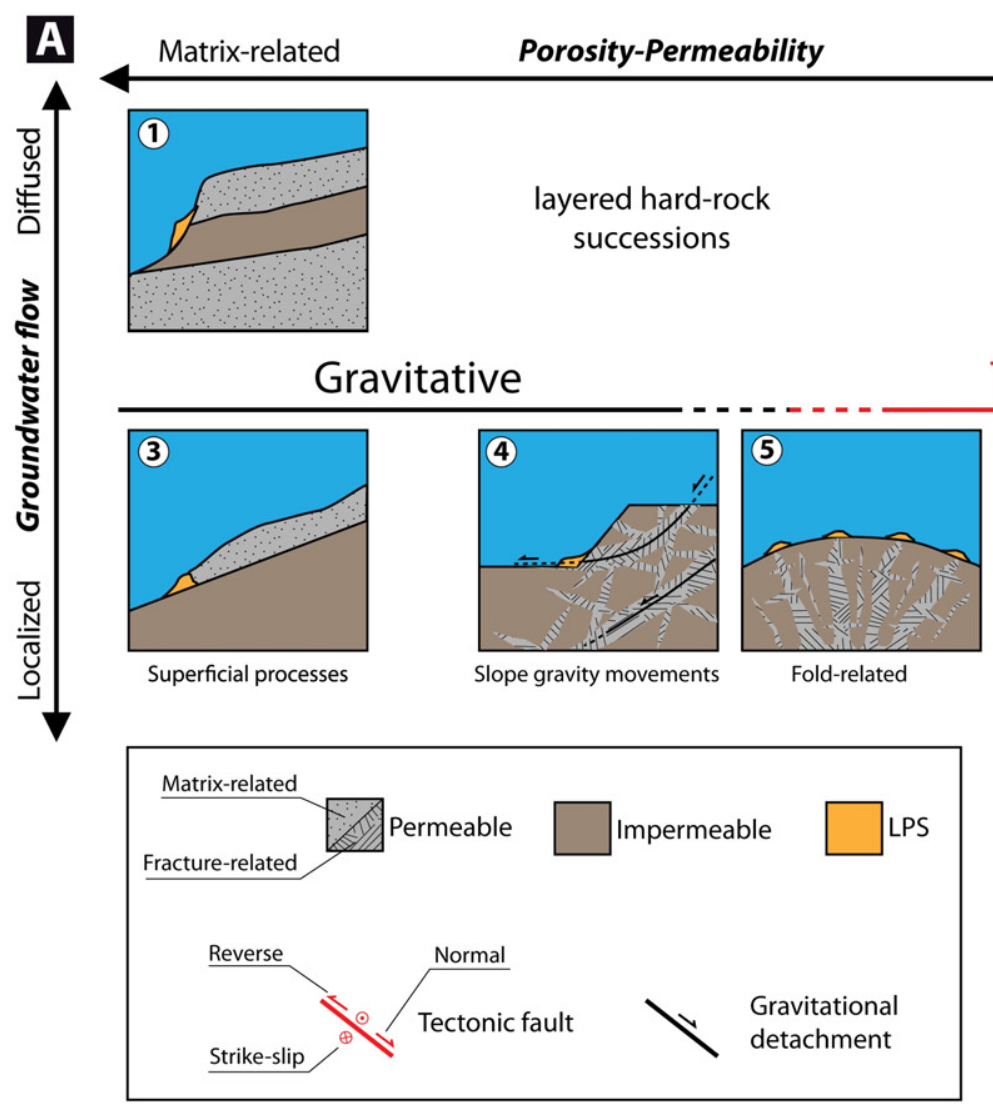

\section{Fracture-related}

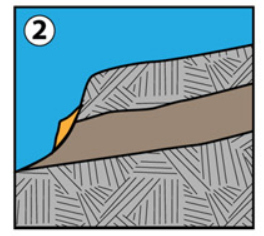

Tectonic
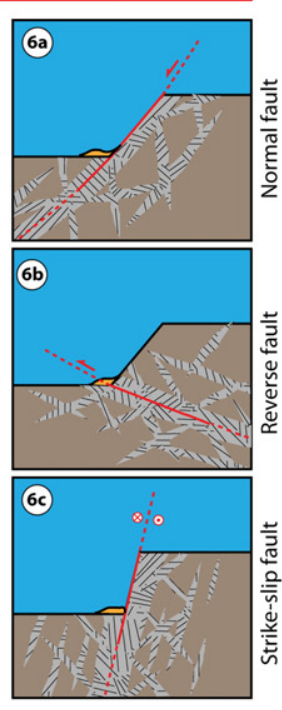

Fault-related

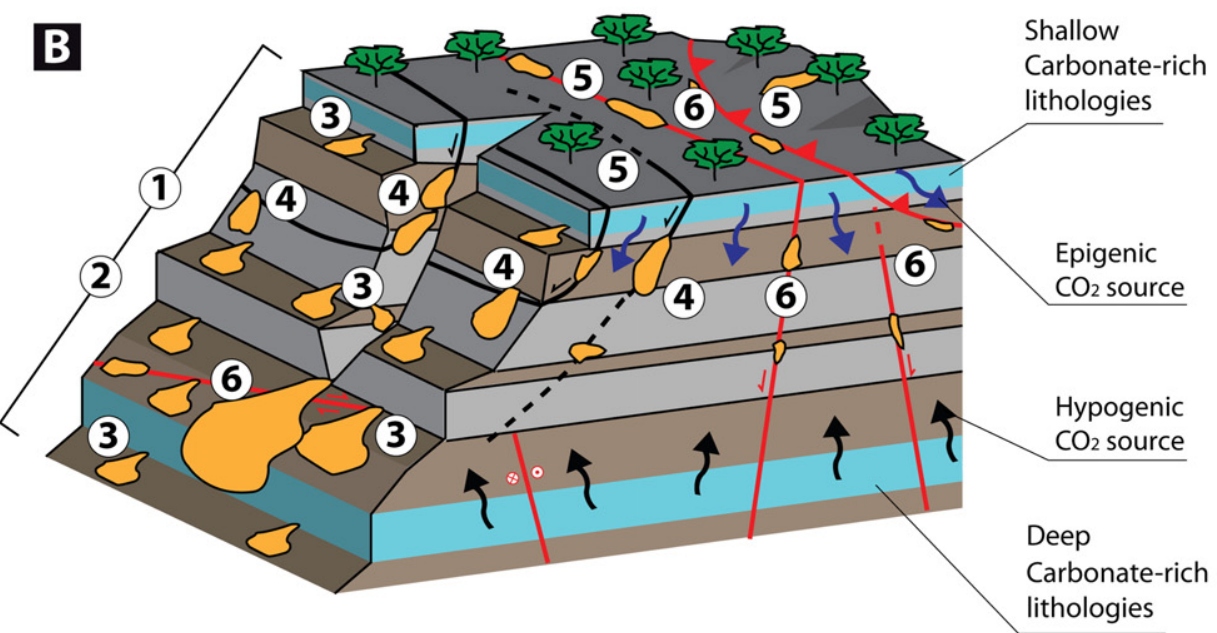

Not to scale

Fig. 2. Diagram illustrating the conceptual model. A. Schematic 2D representation of the 6 type-cases. B. Summary of the occurrence of the type-cases in an hypothetical 3D environment.

system is provided by fracturing (Motyka, 1998). In carbonate rocks, bulk permeability can be enhanced by meteoric dissolution, eventually leading to karst systems; these are not specifically discussed herein.

Type 3 LPS refers to Earth surface processes resulting in unlithified to partly lithified, mostly coarse grained sediment bodies with different fabrics, such as talus, alluvial fans, glacial deposits, as well as rock slides and rock avalanches. LPS are concentrated at the margins of the highly porous and permeable sediment bodies, or where the groundwater level intersects the surface of a thicker deposit (e.g., rockslide masses)(e.g., Sanders et al., 2011). Locally, LPS discharge to the surface is associated with significant cementation within the permeated sediment bodies.

Type 4 LPS is associated with shallow to deep seated gravitational slope deformations. This type of LPS is typical for mountainous areas with high gradient streams and steep relief. In the Apennines, slope gravity movements of $\mathrm{km}$ scale slabs (mainly calciturbidite successions and ophiolites) within shale rich chaotic complexes act as perched isolated aquifers that are effective in producing LPS (Chelli et al., 2013; Gargini et al., 2014; Carlini et al., 2015; Segadelli et al., submitted). 
Type 5 LPS indicates situations where LPS development is due to fracture corridors arrays related to folding and bending of the hydrogeological formations. The classical recurrent example comprises a topographic scale antiform breached by upward fanning, along and cross fold fracture sets, representing preferential fluid escape pathways to the surface (e.g., Evans and Fischer, 2012; Ogata et al., 2014). It is im portant to stress that in this particular case the upward migration of cool water is not driven by temperature but overpressure, due to hypogenic (see below) $\mathrm{CO}_{2}$ degassing in shallow, compartmentalized aquifers (e.g., Dockrill and Shipton, 2010).

Type 6 LPS comprises aquifers partitioned into highly permeable fault damage zones and low permeability fault cores (e.g., Bense et al., 2013). In these cases, LPS occurrence is related to fault pattern. The sub groups $6 a, 6 b$, and $6 c$ are differentiated according to fault character: normal, reverse, or strike slip. The permeability of fault zones is con trolled by the degree of cementation of fracture porosity, and therefore related to depth of deformation, strain type and rate. Along with the fracture network sustaining effective rock leaching in the subsurface, associated morphological relief is an additional factor in providing a structurally controlled pressure gradient for meteoric water percolation.

Among the cases in which the fracture related contribution to permeability prevails, there is a gradual transition from purely gravitational (Type 4 LPS) to entirely tectonic (Type 6 LPS) processes (see Fig. 1a). Deep reaching fault systems (Type 6) and large scale fracture corridors' arrays (Type 5) may promote ascend of hypogenic $\mathrm{CO}_{2}$ rich waters, not necessarily hot, and unrelated to magmatic/ hydrothermal activity. In these cases, the $\mathrm{CO}_{2}$ can be provided by i) oxidation of thermogenic methane, and ii) metamorphism of deeply buried carbonate rocks (e.g., Frery et al., 2015).

The concepts introduced above are similar to those commonly used in the oil and gas industry for the characterization of dual porosity permeability reservoir systems (e.g., Spence et al., 2014), here adapted to conditions where groundwater is the permeating fluid.

\subsection{Worldwide occurrence of LPS types}

Through a careful and detailed review of the inherent literature we compiled a database of recognized LPS types and their locations world wide. As already pointed out above, warm water related LPS strictly as sociated to hydrothermal and magmatic/volcanic processes are excluded. The entire data collection is represented and summarized in Table 3 and Fig. 3.

This compilation, which is function of data availability/quality and intensity of studies in the related regions, is not intended as an exhaus tive database for LPS occurrence, but a geographical distribution of examples used to validate the model. The importance of a robust global database, which is beyond the scope of this work, and the general guidelines to a shared workflow are pointed out in the next section.

Nonetheless a general overlap with the distribution of carbonate rock outcrops exists, LPS appear unrelated to specific environments or lithologies, being by far apparently and relatively underrepresented in karst systems. This suggests that favourable physical chemical bound ary conditions to LPS development might be achieved by different means and interactions, and that the structural control exerted by the geological framework appear to play a fundamental role.

\section{Model application: Limestone-Precipitating Springs territorial information system of the Emilia-Romagna Region (Italy)}

Extended inventories on the LPS distribution are often missing or in complete, mostly because thoroughly field searches of entire geograph ic areas would be extremely expensive and time /energy consuming. Information on their occurrence and conservation status is thus absent or poor.
To overcome this limitation, since 2010, the Geological, Seismic and Soil Survey of Emilia Romagna has activated:

1) the inventorying and cataloguing program of exploited springs (http://ambiente.regione.emilia romagna.it/geologia/cartografia/ webgis banchedati/sorgenti unita geologiche sede acquiferi appennino. Italian version only);

2) the mapping of the main host hydrogeological complexes;

3) the "Habitat map" cartography within Natura 2000 network and regional Parks (http://ambiente.regione.emilia romagna.it/parchi natura2000/consultazione/cartografia interattiva. Italian version only).

The typical aquifers of the Northern Apennines are siliciclastic calcareous turbidites and ophiolites, and the major perennial springs suffer the impacts of a variety of anthropic activities (e.g., mining, drink ing water withdrawal, as for the Labante spring, see below). Few major springs contribute also to the maintenance of environmental flows in streams of the higher mountain range. Another significant threat to these important groundwater resources and related biota is the forced drainage induced by tunnelling for transport infrastructures and/or water abstraction purposes; relevant are the impacts induced by the drilling of the High Speed Railway connection between Bologna and Florence (Gargini et al., 2008; Vincenzi et al., 2014) that caused the per manent vanishing of natural environmental flows during the dry season (summer) and the complete desiccation of major springs.

The inventorying program of the Emilia Romagna Region pointed out the existence of 185 LPS (Fig. 4). These initiatives are promoted to abide by the requests of the Groundwater directive (GWD European Commission, 2006).

Comparing the location of LPS with the distribution of the main hydrogeological complexes in the Emilia Romagna Region, it can be noticed that they preferentially occur near perennial springs fed by groundwater circulation inside carbonate dominated rock aquifers.

The map shown in Fig. 4 represents a first evaluation of the potential LPS prone areas. In particular, from a first screening, the LPS appear to occur mainly within or along the perimeter of the major hydrogeological complexes. Such areas are the starting targets for dedicated investigation strategies aimed to evaluate the true potential for LPS occurrence.

Given the importance of these habitats, any decision making policy aimed at protecting and managing LPS requires the prompt availability and consultation of geographic information stored in a comprehensive database accessible to the public. This kind of Territorial Information System represents the most simple and suitable mean to accomplish this task.

\section{Case study and suggestions for management}

We provide suggestions for an effective and sustainable manage ment discussing a case study in which LPS are left in poor condition be cause of marked water diversion (total during long drought periods), and because of limited awareness of the conservation value of these fragile environments.

The Labante spring (Fig. 5; Table 4) is a LPS located in the northern Apennines (Castel d'Aiano, Bologna). The spring is an important source of drinking water and a site of high environmental and touristic value. It arises at the southern boundary of a large sandstone plate (Pantano For mation, lower Miocene). The aquifer permeability is given by pervasive fracturing related to high angle normal faults. A ranking methodology proposed by Gargini et al. (2008) for Apenninic springs was applied to the spring. In the ranking method, S (Slope) type and $\mathrm{T}$ (Trans water shed) type springs are differentiated according to differential elevation of the spring above the local base level, recession coefficient $\alpha$ and aver age base flow discharge. Labante is classified as T type spring and there fore has the potential to sustain drinking water supply for local communities and to host freshwater habitats (Bertrand et al., 2012). A 
Table 3

Worldwide distribution of recognized LPS used to validate the conceptual model. The characteristic type-cases, geographic location, bibliographic reference, and host lithologies are indicated. Backup reviews and generic compilations: Ford and Pedley (1996); Pedley (2009); Pentecost (2005); Jones and Renaut (2010); Bense et al. (2013); Capezzuoli et al. (2014); Riding (2000).

\begin{tabular}{|c|c|c|c|}
\hline Conceptual LPS type & Location & Lithology & References \\
\hline 4 & $\begin{array}{l}\text { Mt. Carameto, Mt. Pelpi, Mt. Caio, Mt. } \\
\text { Carpegna (northern Apennines, Italy) }\end{array}$ & Interbedded calcarenites and calcareous mudstones & Chelli et al. (2013), Carlini et al. (2015) \\
\hline 6 & Val Pessola (northern Apennines, Italy) & Coarse- to medium-grained sandstones & KO pers. Comm. \\
\hline 3 & Northern Calcareous Alps & Interbedded sandstones and shales & Linhart and Schagerl (2015) \\
\hline $1,2,6$ & East African Rift System & Interbedded sandstones and shales & Ashley et al. (2014) \\
\hline $1,2,6$ & Colorado Plateau (SE Utah, USA) & Interbedded sandstones-mudstones & $\begin{array}{l}\text { Gratier et al. (2012), Frery et al. (2015), } \\
\text { Priewisch et al. (2014); Ricketts et al. (2014) }\end{array}$ \\
\hline $1,2,3$ & Western Alps (Central Switwerland) & Different lithologies & Wehrli et al. (2010) \\
\hline 5,6 & SE Utah (USA) & Interbedded sandstones-mudstones & Dockrill and Shipton (2010), Ogata et al. (2014) \\
\hline 5,6 & New Mexico (USA) & Interbedded sandstones-mudstones & Crumpler (2003) \\
\hline 6 & East-central Utah & Interbedded sandstones-mudstones & Jung et al. (2014) \\
\hline $1,2,6$ & Eastern Tunisia & Different lithologies & Essefi et al. (2014) \\
\hline 4 & Sierra del Montsec (Pyrenees, Spain) & Biohermal limestones & Rosell and Linares (2001) \\
\hline $1,2,6$ & Itaboraí basin (Southeastern Brazil) & Basement rocks with sedimentary cover & Sant'Anna et al. (2004) \\
\hline $1,2,3,4,6$ & Eastern Alps (Europe) & Carbonate and calciclastic deposits & $\begin{array}{l}\text { Sanders et al. (2010a, 2010b), Sanders } \\
\text { and Rott (2009), Sanders et al., (2011) Gargini }\end{array}$ \\
\hline 6 & Labante (northern apennines, Italy) & Medium- to fine-grained calcarenites & et al. (2012) \\
\hline 2,6 & South Tibet & $\begin{array}{l}\text { Metamporhosed carbonate and siliciclastic, } \\
\text { and crystalline rocks }\end{array}$ & Zentmyer et al. (2008) \\
\hline $2,4,6$ & Southern Apennines (Italy) & Carbonate and calciclastic deposits & Ascione et al. (2013) \\
\hline $1,2,6$ & Kerch Peninsula (Crimea, Russia/Ukraine) & Layered limestones & Kokh et al. (2015) \\
\hline 1,2 & Fossil Creek (Arizona, USA) & Mainly aeolian sandstones & Schleicher (2011) \\
\hline 1,2 & Dalhousie Springs (Australia) & Mainly siliciclastic deposits & Clarke and Bourke (2011) \\
\hline \multirow[t]{2}{*}{5,6} & Poland, central and western Carpathians & Biohermal limestones & Mastella and Rybak-Ostrowska (2012) \\
\hline & South Australia & Different lithologies & Keppel et al. (2011) \\
\hline $2,5,6$ & Oman & Ophiolites & Olsson et al. (2014) \\
\hline $2,5,6$ & Sierra de Alfaguara (Granada. southern Spain) & $\begin{array}{l}\text { Calcarenites, limestones, gypsum, marls, } \\
\text { sandstones and claystones }\end{array}$ & $\begin{array}{l}\text { Martín-Algarra et al. (2003), } \\
\text { Andreo et al., (1999), Prado-Pérez et al. (2013) }\end{array}$ \\
\hline $2,5,6$ & Northern Australia, Barkly karst & Limestones and dolomites & Carthew et al. (2006) \\
\hline $1,2,6$ & Expedition Fjord, Canadian High Arctic & Gypsum-anhydrite & Omelon et al. (2000) \\
\hline 1,2 & Santa Barbara, California (USA) & Limestones and calcareous mudstones & Ibarra et al. (2014) \\
\hline 5,6 & Longmenshan, southwestern China & Mixed with dominant carbonates & Shi et al. (2014) \\
\hline $2,5,6$ & Plitvice, Croatia & Limestones and dolomites & Golubić et al. (2008) \\
\hline 2,6 & Slieve Bloom, Ireland & Limestones and dolomites & Heery (2007) \\
\hline $1,2,6$ & High Andes, Argentina & Conglomerates, sandstones, and intraclastic limestones & Valero-Garcés et al. (2001) \\
\hline $1,2,6$ & Taung, South Africa & Limestones and clastic-soil cover & McKee (2010) \\
\hline $1,2,6$ & Sears Lake, Califoprnia (USA) & Conglomerates, sandstones, and intraclastic limestones & Guo and Chafetz (2012) \\
\hline $1,2,6$ & High Andes, Peru & Different lithologies & Acosta and Prat (2011) \\
\hline $2,5,6$ & Paris Basin, France & Limestones and clastic-soil cover & Freytet and Plet (1996) \\
\hline $1,2,6$ & Pyramid Lake, Nevada & Unlithified lithologies & Benson (2004) Pedley \\
\hline 1,3 & Guadalajara, Spain & Unlithified lithologies & et al. (2003) \\
\hline
\end{tabular}

recharge area of $2.61 \mathrm{~km}^{2}$ was determined for the spring via numerical modelling (Gargini et al., 2014; Piccinini et al., 2014).

Carbonate rich groundwater arising from the spring allows the de position of SAL, which occurs in correspondence of a morphologic drop able to produce a spring waterfall. SAL deposits grow at the water fall front with the formation of a prograding flat surface. An important system of primary caves (the biggest in Italy) is hosted in these deposits. The caves and the waterfall represent the main touristic attractions of the site, while at least three different habitats hosted in the SAL (follow ing the EU Habitat directive; EU HD, 1992) are main grounds for its nat uralistic and environmental interest as a Groundwater Dependent Ecosystem (GDE).

The Labante site (i.e. caves and waterfall) has been affected by human activities since the ancient age (e.g., exploitation of SAL as build ing materials in the Etruscan age, cave frequentation). Until a decade ago the site was in a general state of abandon and decadence, due to lack of guidelines and regulations for its preservation. Since 1993 the spring is exploited to gain drinking water. The water diversion occurs up gradient from the SAL deposits (Fig. 5), causing a significant de crease of flow rate at the waterfall (up to $85 \%$ during the dry season). This produced a significant decrease in the progradation rate of the SAL front during the last two decades (Piccinini et al., 2014).

Despite the significant impact of water diversion, a biological survey based on sampling performed in 2011 revealed the occurrence of one of the most characteristic SAL species: the microalga Oocardium stratum
(ER, unpublished data). Moreover, the typical LPS mosses Palustriella commutatata and Eucladium verticillatum were found to be dominant among bryophytes (Daniel Spitale, unpublished data). Among the diatom microalgae several species characteristic of LPS springs including hygropetric microhabitats were found (e.g., Gomphonema lateripunctatum, Delicata minuta, Denticula elegans, Cymbella diminuta). This characteristic biota is not concentrated in the waterfall (where more widespread rheophilic species prevail) but distributed on the wet flanks of the large SAL complex. To ensure the protection of this biota and prevent deterioration, it is thus necessary to change the runoff pattern, now somewhat channelled towards the waterfall for scenic rea sons (Fig. 5), into a more diffuse seepage on wide surfaces of the SAL complex. A minimum sustainable discharge towards the SAL complex should be warranted and estimated by means of tailored biological and geological (SAL deposition rates etc.) investigations.

In order to restore conflicts between human exploitation and GDE protection several measures have been developed and adopted since the last fifteen years: 1) the Labante site was included in several net works at the regional, national, and international scale (e.g., the European "Natura 2000" network, as "Site of Community Importance"); 2) hydrogeological researches were performed to identify the spring re charge area and to define a physically based protection area (Piccinini et al., 2014); 3) public meetings were organized with the stakeholders (local authorities and citizens) in order to raise awareness on the natu ralistic and environmental significance of the site; 4 ) guidelines were 


\section{Worldwide LPS distribution by types}

(case studies used to validate the model)

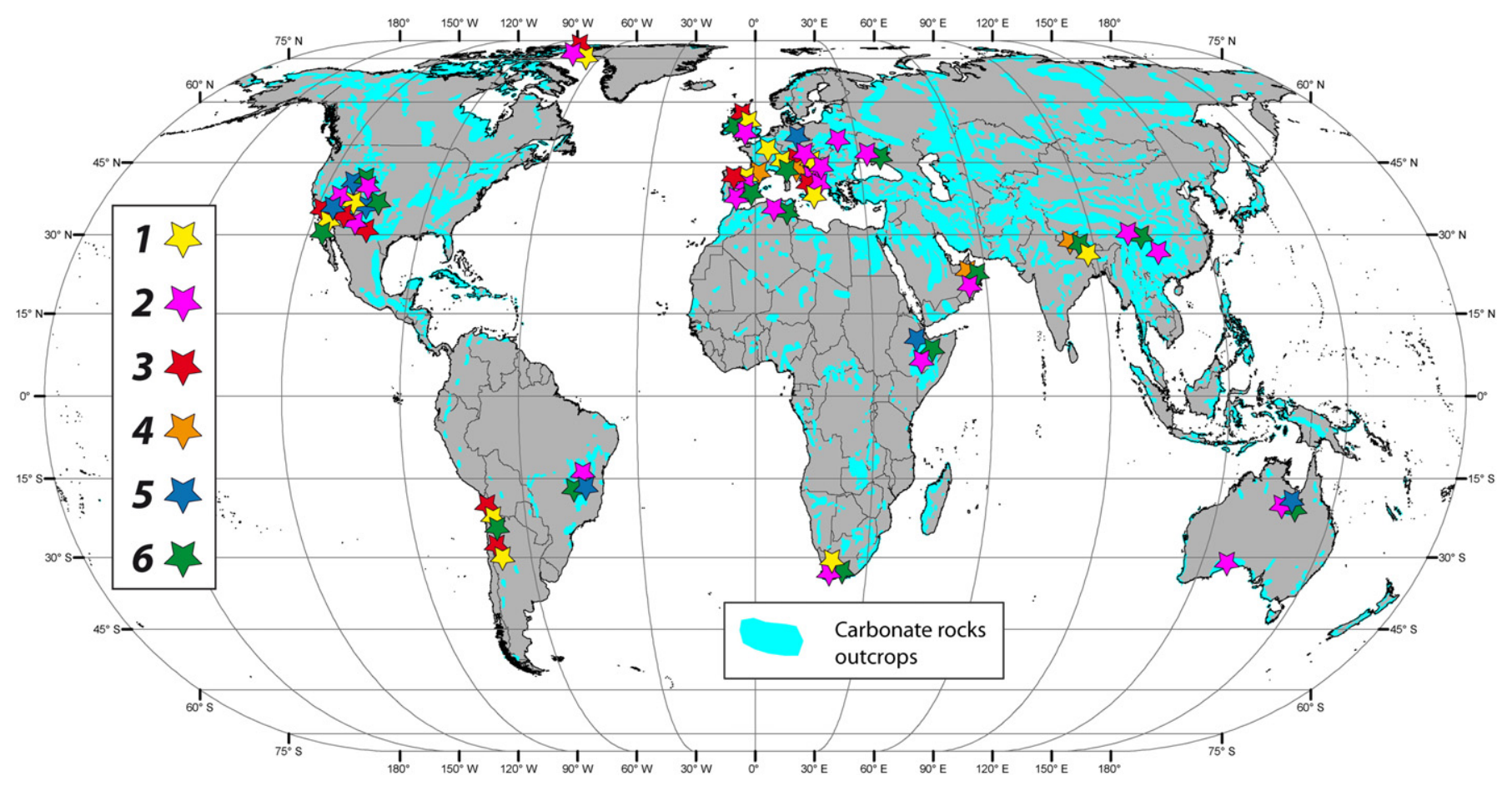

Source: University of Auckland (New Zealand) - http://web.env.auckland.ac.nz/our_research/karst/

Fig. 3. Map showing the worldwide distribution of LPS types recognized in the available literature.

compiled to address the management of the drinking water exploita tion (minimum sustainable flow) and the site conservation (sustainable tourism, e.g.: proper access ways, monitoring of human activities poten tially negative for the GDE).

\section{Conclusions}

Springs and spring associated limestones have been classified be fore with highly different perspectives (e.g., according to types of

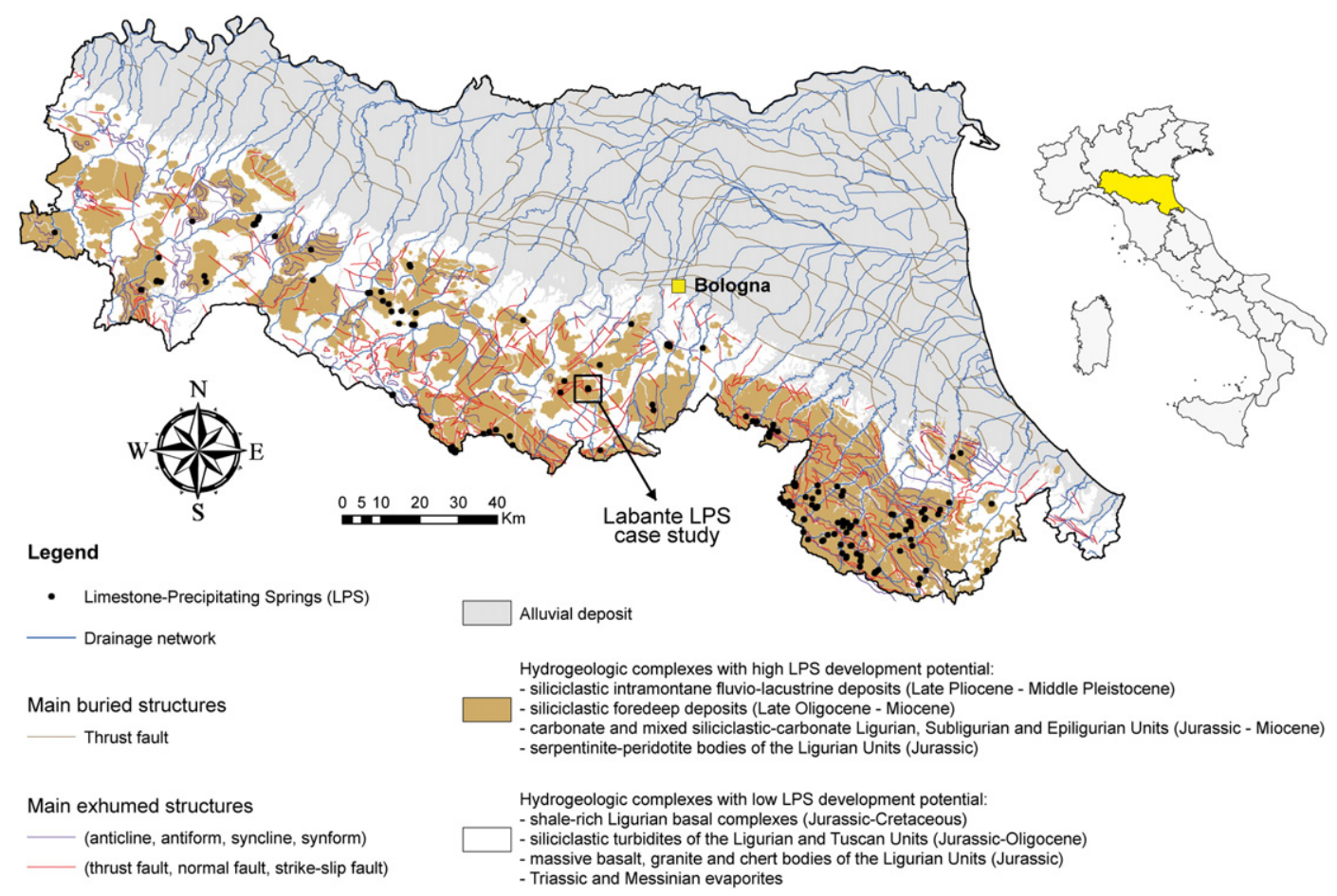

Fig. 4. Areas of high incidence of LPS occurrence as predicted by the conceptual model for the Emilia-Romagna Region. Recognized and ground-verified LPS are marked. 

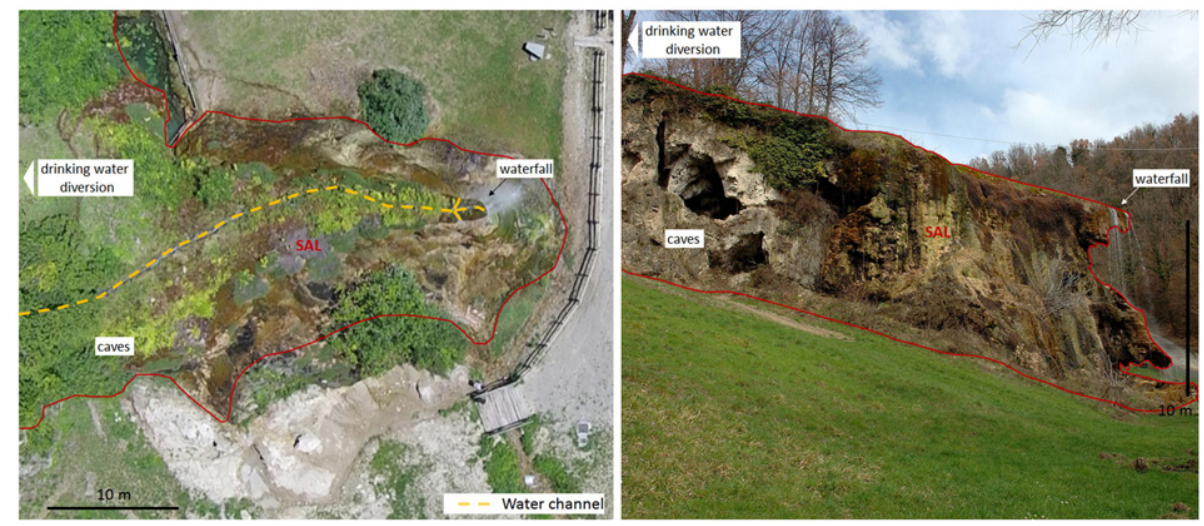

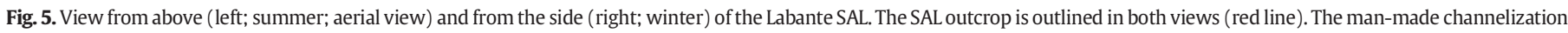
of water towards the waterfall is highlighted on the aerial view (yellow line).

sedimentary facies, geomorphology, or botany) (see also review in Ford and Pedley, 1996). Our classification presented herein emphasizes the combined structural geomorphological hydrogeological aspect of LPS, so it seems best suited for regions of differentiated relief, such as high lands and mountain ranges. Our concept is not explicit on the type, facies architecture or size of spring limestone deposystems; these features can be categorized in classification schemes presented previ ously (e.g. Pedley, 1990; Ford and Pedley, 1996; Carthew et al., 2003; Capezzuoli and Gandin, 2004; Jones and Renaut, 2010; Keppel et al., 2011). In mountain ranges, because of topographic relief and steep slopes, by far most spring limestone deposystems may pertain to the 'perched springline (slope system)' type of Ford and Pedley (1996, p. 123 f.). To achieve a more distinguishing characterization, depending on area, it may be desirable to further divide the perched springline type into subgroups (e.g., Sanders et al., 2010a, 2010b). Travertines or hot spring limestones commonly are associated with volcanism and/or with active faults guiding fluid ascend; therefore, travertines can be recorders of neotectonic deformation (e.g., Hancock et al., 1999; Minissale et al., 2002; Capezzuoli and Sandrelli, 2006; Zentmyer et al., 2008; De Filippis and Billi, 2012). With respect to the association of trav ertines with faults, mainly the structural aspects of our concept also are applicable to hot LPS.

Herein, Limestone Precipitating Springs (LPS) are understood as springs of ambient temperature waters (no geothermal contribution) that achieve sufficient oversaturation for $\mathrm{CaCO}_{3}$ mainly by physical $\mathrm{CO}_{2}$ degassing and photosynthetic activity to deposit limestone.

LPS support specific calcifying organisms, mainly cyanobacteria, algae, and mosses. The invertebrate fauna is of low diversity, and is limited to a very few adapted specialists coexisting with several generalists tolerating the permanent environmental stress by carbonate precipitation.

LPS are found on all continents but do not have a special protection status in most countries yet. This contrasts with the current situation in Europe where LPS are the most protected spring type (listed in Annex of the Habitat Directive). Special protection status is primarily due to aesthetic, cultural and touristic reasons, and only secondarily to the scientific interest as key sites for ongoing geogenic processes including biocalcification.

\section{Table 4}

Hydrodynamic, physical, chemical, and topographic features of the Labante spring. Data obtained from a continuous monitoring performed at spring 2003 and in 2010-2011.

\begin{tabular}{lccc}
\hline & $\min$ & $\max$ & mean \\
\hline Altitude $(\mathrm{m}$ a.s.l. $)$ & & 612 & \\
$\mathrm{Q}\left(\mathrm{L} \mathrm{s}^{1}\right)$ & 3 & 28 & 13 \\
$\mathrm{~T}\left({ }^{\circ} \mathrm{C}\right)$ & 8.5 & 12.9 & 10.8 \\
Conductivity $25^{\circ} \mathrm{C}\left(\mu \mathrm{S} \mathrm{cm}{ }^{1}\right)$ & 623 & 639 & 626 \\
$\mathrm{pH}$ & 7.4 & 8.0 & 7.7 \\
\hline
\end{tabular}

To support mapping of LPS in fulfilment of the Habitat Directive, we developed a conceptual model based on fundamental stratigraphic and structural conditions to predict where LPS are more likely to occur in a particular region, with a focus on the geologic structure. This should facilitate an integrated view on spring phenomena and help optimizing management. The main impacts on LPS are due to inappropriate man agement underlain by missing awareness. It is thus important to dis seminate knowledge on spring habitats, and to urge the application of flow splitters to sustain long term persistence of key biota.

In Europe, a focus on LPS has the potential to flagship a more wide spread and effective conservation of springs in general, since natural springs other than LPS harbour even much higher diversity of biota.

\section{Acknowledgements}

This paper is part of the STOTEN virtual special issue, titled 'The relevance and potential of benthic algae for present day freshwater eco logical assessments'. This work was partially supported by the EBERs Project (Exploring the Biodiversity of Emilia Romagna springs; Emilia Romagna Region official record N. PG.2011.0147111, June $15^{\text {th }} 2011$ ) funded by the Geological Survey of the Emilia Romagna Region. We thank Nicola Angeli (Limnology \& Phycology, MUSE Trento) for the lay out of Fig. 1. Financial support from Project 911 of the OeAD Vietnam Austria PhD Scholarship Programme (to HT) is gratefully acknowl edged. We are grateful to the following Colleagues who were contacted to check worldwide information on LPS and spring habitat protection: Renee Rossini (University of Queensland, St Lucia, Australia), Patrick Rioual (Institute of Geology \& Geophysics, Chinese Academy of Sci ences), Svetlana Smirnova (Komarov Botanical Institute RAS, St. Peters burg, Russia), Abdullah A. Saber (Ain Shams University, Cairo, Egypt), Jonathan Taylor (North West University, Potchefstroom, South Africa), Larry Stevens (Springs Stewardship Institute, Flagstaff, AZ, USA), Roberto da Gama Alves (Federal University of Juiz de Fora, Brazil).

\section{References}

Acosta, R., Prat, N., 2011. Trophic ecology of Hyalella sp. (Crustacea: Amphipoda) in a High Andes Headwater River with travertine deposits. Int. Rev. Hydrobiol. 96, 274-285. Ague, J.J. 2000. Release of $\mathrm{CO}_{2}$ from carbonate rocks during regional metamorphism of lithologically heterogeneous crust. Geology 28, 1123-1126.

Alfaro, C., Wallace, M., 1994. Origin and classification of springs and historical review with current applications. Environ. Geol. 24, 112-124.

Andreo, B., Martín-Martín, M., Martín-Algarra, A., 1999. Hydrochemistry of spring water associated with travertines. Example of the Sierra de la Alfaguara (Granada, southern Spain). Earth Planet. Sci. 328, 745-750.

Arenas, C., Osácar, C., Sancho, C., Vázquez-Urbez, M., Auque, L., Pardo, G., 2010. Seasonal record from recent fluvial tufa deposits (Monasterio de Piedra, Spain): sedimentolog-ical and stable isotope data. In: Pedley, H.M., Rogerson, M. (Eds.), Tufas and Speleothems: Unravelling the Microbial and Physical ControlsGeological Society of 
London, Special Publication 336. The Geological Society of London, London, pp. 119-142.

Ascione, A., Iannace, A., Imbriale, P., Santangelo, N., Santo, A., 2013. Tufa and travertines of southern Italy: deep-seated, fault related $\mathrm{CO}_{2}$ as the key control in precipitation. Terra Nova 1-13 (0).

Ashley, G.M., De Wet, C.B., Domínguez-Rodrigo, A., Karis, A.M., O'Reilly, T.M., Baluyot, R., 2014. Freshwater limestone in an arid rift basin: a goldilocks effect. J. Sediment.

Res. 84, 988-1004.

Bauer, W., Golowin, S., Zerling, C., 2009. Heilige quellen, heilende brunnen. Neue Erde, Saarbrücken (160 pp. ISBN: 978-3-89060-275-2).

Becker, M.W., Shapiro, A.M., 2000. Tracer transport in fractured crystalline rock: evidence of non diffusive breakthrough tailing. Water Resour. Res. 36 (7), 1677-1686.

Bense, V.F., Gleeson, T., Loveless, S.E., Bour, O., Scibek, J., 2013. Fault zone hydrogeology Earth Sci. Rev. 127, 171-192.

Benson, L., 2004. The Tufas of Pyramid Lake, Nevada (USGS online report: 14 pp.).

Bertrand, G., Goldscheider, N., Gobat, J.-M., Hunkeler, D., 2012. Review: from multi-scale conceptualization to a classification system for inland groundwater-dependent eco-

systems. Hydrogeol. J. 20 (1), 5-25.

Bischoff, J.L., Fyfe, W.S., 1968. Catalysis, inhibition, and the calcite-aragonite problem. Am. J. Sci. 266, 65-79.

Bissig, P., Goldscheider, N., Mayoraz, J., Surbeck, H., Vuataz, F.-D., 2006. Carbogaseous

spring waters, coldwater geysers and dry $\mathrm{CO}_{2}$ exhalations in the tectonic window of the Lower Engadine Valley, Switzerland. Eclogae Geol. Helv. 99, 143-155.

Boch, R., Spötl, C., Reitner, J.M., Kramers, J., 2005. A lateglacial travertine deposit in Eastern Tyrol (Austria). Aust. J. Earth Sci. 98, 78-92.

Burmeister, E.-G., Reiss, F., 2003. Rheotanytarsus reissi, eine zweite tuffbildende Wasserinsektenart (Diptera, Chironomidae). Lauterbornia 48, 77-88.

Cantonati, M., Füreder, L., Gerecke, R., Jüttner, I., Cox, E.J., 2012a. Crenic habitats, hotspots for freshwater biodiversity conservation: toward an understanding of their ecology. In: Cantonati, M., Füreder, L., Jüttner, I., Cox, E.J. (Eds.), The Ecology of Springs. Fresh-water Science 31, pp. 463-480.

Cantonati, M., Rott, E., Spitale, D., Angeli, N., Komárek, J., 2012b. Are benthic algae related to spring types? In: Cantonati, M., Füreder, L., Jüttner, I., Cox, E.J. (Eds.), The Ecology of

Springs. Freshwater Science 31, pp. 481-498

Cantonati, M., Angeli, N., Bertuzzi, E., Spitale, D., Lange-Bertalot, H., 2012c. Diatoms in springs of the Alps: spring types, environmental determinants, and substratum. Freshw. Sci. 31, 499-524.

Capezzuoli, E., Gandin, A., 2004. I "travertini” in Italia: Proposta di una nomenclatura basta sui caratteri genetici. Il Quaternario. Ital. J. Quat. Sci. 17, 273-284.

Capezzuoli, E., Sandrelli, F., 2006. Neotectonic evidence in the Quaternary continental carbonates from southern Valdelsa basin (Tuscany). Il Quaternario. Ital. J. Quat. Sci. 19, 155-166.

Capezzuoli, E., Landin, A., Pedley, M., 2014. Decoding tufa and travertine (fresh water carbonates) in the sedimentary record: the state of the art. Sedimentology 61,1-21. Carlin M., Chelli, A., Vescovi, P., Artoni, A., Clemenzi, L., Tellini, C., Torelli, L., 2015. Tectonic control on the development and distribution of large landslides in the Northern Apennines (Italy). Geomorphology http://dx.doi.org/10.1016/j.geomorph.2015.10.028.

Carthew, K.D., Taylor, M.P., Drysdale, R.N., 2003. Are current models of tufa sedimentary environments applicable to tropical systems? A case study from the Gregory River. Sediment. Geol. 162, 199-218.

Carthew, K.D., Taylor, M.P., Drysdale, R.N., 2006. An environmental model of fluvial tufas 100. in the monsoonal tropics, Barkly karst, northern Australia. Geomorphology 73, 78-

Celico, F., Naclerio, G., Bucci, A., Nerone, V., Capuano, P., Carcione, M., Allocca, V., Celico, P. 2010. Influence of pyroclastic soil on epikarst formation: a test study in southern Italy. Terranova $22,110-115$

Chakraborty, R., Coates, J.D., 2004. Anaerobic degradation of monoaromatic hydrocarbons Appl. Microbiol. Biotechnol. 64 (4), 437-446.

Chan, C.S., Fakra, S.C., Edwards, D.C., Emerson, D., Banfield, J.F., 2009. Iron oxyhydroxide mineralization on microbial extracellular polysaccharides. Geochim. Cosmochim.

Acta 73, 3807-3818.

Chelli, A., Ruffini, A., Vescovi, P., Tellini, C., 2013. Tectonics of large landslides in the Northern Apennines (Italy). In: Margottini, et al. (Eds.), Landslide Science and Practice 1, pp. 273-279.

Chen, J., Zhang, D.D., Wang, S., Xiao, T., Huang, R., 2004. Factors controlling tufa deposition in natural waters at waterfall sites. Sediment. Geol. 166, 353-366.

Civita, M., 1973. Schematizzazione idrogeologica delle sorgenti normali e delle relative opera di captazione (Hydrogeological scheme of normal springs and catchment

structures). Italian. Memorie e Note Ist. Geol. Applic. Napoli. 12, pp. 1-34.

Clarke, F.W., 1924. Mineral wells and springs. The data of geochemistry. US Geological Survey, Reston, VA, pp. 181-217.

Clarke, J.D.A., Bourke, M.C., 2011. Travertine and tufa from Dalhousie Springs (Australia)-implications for recognizing Martian springs. In: Garry, W.B., Bleacher, J.E. (Eds.), Analogs for Planetary exploration. Geological Society Of America Special Paper 483, pp. 231-247.

Crumpler, L.S., 2003. Physical characteristics, geologic setting, and possible formation process of spring deposit on Mars based on terrestrial analogs. Sixth International Con-

ference on Mars, p. 3228 (4 pp.).

De Filippis, L., Billi, A., 2012. Morphotectonics of fissure ridge travertines from geotherma areas of Mammoth Hot Springs (Wyoming) and Bridgeport (California). Tectonophysics 548-549, 34-48.

Dierssen, K., 2001. Distribution, ecological amplitude and phytosociological characterization of European bryophytes. Bryophytorum Bibliotheca, Band 56, J. Cramer, Berlin, Stuttgart (289 pp.).

Dittrich, M., Sibler, S., 2010. Calcium carbonate precipitation by cyanobacterial polysaccharides. In: Pedley, H.M., Rogerson, M. (Eds.), Tufas and Speleothems: Unravelling the Microbial and Physical ControlsGeological Society of London, Specia

Publication 336. The Geological Society of London, London, pp. 51-63.

Dockrill, B., Shipton, Z.K., 2010. Structural controls on leakage from a natural CO2 geologic storage site: Central Utah, U.S.A. J. Struct. Geol. 32, 1768-1782.

Dromgoole, E.L., Walter, L.M. 1990. Iron and manganese incorporation into calcite: effects of growth kinetics, temperature and solution chemistry. Chem. Geol. 81, 311-336.

Dürrenfeldt, A., 1978. Untersuchungen zur Besiedlungsbiologie von Kalktuff faunistische, ökologische und elektronenmikroskopische Befunde. Arch. Hydrobiol. Suppl. 54 (1), 1-79.

Ellenberg H.H. 2009. Vegetation ecology of Central Europe. 4th Edition. Translator: G.K. Strutt. 756 pp. ISBN: 9780521115124

Engelhardt, C., Haase, P., Pauls, S.U., 2011. From the Western Alps across Central Europe: postglacial recolonisation of the tufa stream specialist Rhyacophila pubescens (Insecta, Trichoptera). Front. Zool. 8, 10. http://dx.doi.org/10.1186/1742-9994-8-10.

Essefi, E., Komatsu, G., Fairén, A.G., Chan, M.A., Yaich, C., 2014. Models of formation and activity of spring mounds in the Mechertate-Chrita-Sidi El Hani System, Eastern Tunisia: implications for the habitability of Mars. Life 4, 386-432.

EU-HD (European Union Habitat Directive), 1992. Council Directive 92/43/EEC of 21 May 1992 on the conservation of natural habitats and of wild fauna and flora (EC Habitats

Directive). Off. J. Eur. Communities L 206, 7-50 (22.7.1992).

European Commission, 2006. Directive 2006/118/EC of the European Parliament and the council, of 12 December 2006, on the protection of groundwater against pollution and deterioration (GWD). Off. J. Eur. Communities L 372 (19) (Luxembourg).

Evans, M.A., Fischer, M.P., 2012. On the distribution of fluids in folds: A review of controlling factors and processes. J. Struct. Geol. 44, 2-24.

Fensham, R.J., Silcock, J.L., Powell, O., Habermehl, M.A., 2015. In search of lost springs: a protocol for locating active and inactive springs. Groundwater http://dx.doi.org/10. 1111/gwat.12375 (in press).

Fernández-Díaz, L., Fernández-González, A., Prieto, M., 2010. The role of sulfate groups in controlling $\mathrm{CaCO}_{3}$ polymorphism. Geochim. Cosmochim. Acta 74, 6064-6076. Feuerborn, H.J., 1923. Die Larven der Psychodiden oder Schmetterlingsmücken. Ein

Beitrag zur Ökologie des „Feuchten“. Verh. Int. Ver. Theor. Angew. Limnol. 1, 181-213. Flora of North America Editorial Committee, eds. 1993+. Flora of North America North of Mexico. 19+ vols. New York and Oxford.

Flügel, E., 2004. Microfacies of Carbonate Rocks (976 pp.) Springer, Berlin.

Ford, T.D., Pedley, H.M., 1996. A review of tufa and travertine deposits of the world. Earth Sci. Rev. 41 (3-4), 117-175.

Frery, E., Gratier, J.-P., Ellouz-Zimmerman, N., Loiselet, C., Braun, J., Dechamps, P., Blamart, D., Hamelin, B., Swennen, R., 2015. Evolution of fault permeability during episodic fluid circulation: evidence for the effects of fluid-rock interactions from travertine studies (Utah-USA). Tectonophysics 651-652, 121-137.

Freytet, P., Plet, A., 1996. Modern freshwater microbial carbonates: the Phormidium stromatolites (tufa-travertine) of southeastern Burgundy (Paris Basin, France). Facies 34 219-238.

Freytet, P., Verrecchia, E.P., 1998. Freshwater organisms that build stromatolites: a synopsis of biocrystallization by prokaryotic and eukaryotic algae. Sedimentology $45,535-563$

Gargini, A., Vincenzi, V., Piccinini, L., Zuppi, G., Canuti, P., 2008. Groundwater flow systems in turbidites of the Northern Apennines (Italy): natural discharge and high speed rail-

way tunnel drainage. Hydrogeol. J. 16 (8), 1577-1599.

Gargini, A., Piccinini, L., De Nardo, M.T., 2012. Studio idrogeologico dell'area di San Cristoforo di Labante, Comune di Castel D'Aiano (BO). University of Ferrara/ Regione Emilia-Romagna internal report (47 pp.).

Gargini, A., De Nardo, M.T., Piccinini, L., Segadelli, S., Vincenzi, V., 2014. Spring discharge and groundwater flow systems in sedimentary and ophiolitic hard rock aquifers: ex-periences from Northern Apennines (Italy). In: Sharp, J.M. (Ed.), Fractured Rock Hy-drogeology. CRC Press, pp. 129-143.

Gerecke, R., 2009. Revisional studies on the European species of the water mite genus Lebertia Neuman, 1880 (Acari: Hydrachnidia: Lebertiidae). Abh. Senckenb.

Naturforsch. Ges. 566, 1-144.

Gerecke, R., Di Sabatino, A., 1996. Water mites (Acari, Hydrachnellae) and spring typology in Sicily. Crunoecia 5, 35-41.

Glassley, W.E., 1983. Deep crustal carbonates as CO2 fluid sources: evidence from metasomatic reaction zones. Contrib. Mineral. Petrol. 84 (1), 15-24.

Glazier, D.S., 2009. Springs. In: Likens, G.E. (Ed.), Encyclopedia of Inland Waters 1. Academic Press Elsevier, Oxford, pp. 734-755.

Golubić, S., Violante, C., Plenković-Moraj, A., Grgasović, T., 2008. Travertines and calcareous tufa deposits: an insight into diagenesis. Geol. Croat. 61, 363-378.

Gradzinski, M., 2010. Factors controlling growth of modern tufa: results of a field experiment. In: Pedley, H.M., Rogerson, M. (Eds.), Tufas and Speleothems: Unravelling the Microbial and Physical ControlsGeological Society of London, Special Publication 336. The Geological Society of London, London, pp. 143-191.

Gratier, J.-P., Frery, E., Deschamps, P., Røyne, A., Renard, F., Dysthe, D., Ellouz-Zimmerman, N., Hamelin, B., 2012. How travertine veins grow fromtop to bottomand lift the rocks abe them: the effect of crystallization force. Geology 40, 1015-1018.

Guo, X., Chafetz, H.S., 2012. Large tufa mounds, Searles Lake, California. Sedimentology 59, 1509-1535.

Hancock, P.L., Chalmers, R.M.L., Altunel, E., Cakir, Z., 1999. Travitonics: using travertines in active fault studies. J. Struct. Geol. 21 (8-9), 903-916.

Hartmann, A., Goldscheider, N., Wagener, T., Lange, J., Weiler, M., 2014. Karst water resources in a changing world: review of hydrological modeling approaches. Rev.

Geophys. 52, 218-242.

Heery, S., 2007. A survey of tufa-forming (petrifying) springs in the Slieve Bloom, Ireland. Report for Offaly \& Laois County Councils (55 pp.).

House, W.A., 1987. Inhibition of calcite crystal growth by inorganic phosphate. J. Colloid Interface Sci. 119, 505-511. 
Ibarra, Y., Corsetti, F.A., Cheetham, M.I., Feakins, S.J., 2014. Were fossil spring-associated carbonates near Zaca Lake, Santa Barbara, California deposited under an ambient or thermal regime? Sediment. Geol. 301, 15-25.

Jones, B., Renaut, R.W., 2010. Calcareous spring deposits in continental settings. In: Alonso-Zarza, A.M., Tanner, L.H. (Eds.), Carbonates in Continental Settings: Facies, En-vironments, and Processes 61. Elsevier, pp. 177-224.

Jung, N.-H., Han, W.S., Watson, Z.T., Graham, J.P., Kim, K.-Y., 2014. Fault-controlled $\mathrm{CO}_{2}$ leakage from natural reservoirs in the Colorado Plateau, East-Central Utah. Earth

Planet. Sci. Lett. 403, 358-367.

Kano, A., Matsuoka, J., Kojo, Fujii T., 2003. Origin of annual laminations in tufa deposits, southwest Japan. Palaeogeogr. Palaeoclimatol. Palaeoecol. 191, 243-262.

Kawaguchi, T., Decho, A.W., 2002. A laboratory investigation of cyanobacterial extracellular polymeric secretions (EPS) in influencing $\mathrm{CaCO}_{3}$ polymorphism. J. Cryst. Growth 240, 230-235.

Kawai, T., Kano, A., Matsuoka, J., Ihara, T., 2006. Seasonal variation in water chemistry and depositional processes in a tufa-bearing stream in SW-Japan, based on 5 years of monthly observations. Chem. Geol. 232, 33-53.

Keppel, M.N., Clarke, J.D.A., Halihan, T., Love, A.J., Werner, A.D., 2011. Mound springs in the arid Lake Eyre south region of South Australia: A new depositional tufa model and its controls. Sediment. Geol. 240, 55-70.

Kløve, B., Ala-aho, P., Bertrand, G., Boukalova, Z., Ertürk, A., Goldscheider, N., Ilmonen, J., Karakaya, N., Kupfersberger, H., Kvœrner, J., Lundberg, A., Mileusnić, M., Moszczynska, A., Muotka, T., Preda, E., Rossi, P., Siergieiev, D., Šimek, J., Wachniew, P. Angheluta, V., Widerlund, A., 2011a. Groundwater dependent ecosystems. Part I: hydroecological status and trends. Environ. Sci. Pol. 14 (7), 770-781.

Kløve, B., Allan, A., Bertrand, G., Druzynska, E., Ertürk, A., Goldscheider, N., Henry, S., Karakaya, N., Karjalainen, T.P., Koundouri, P., Kupfersberger, H., Kvœrner, J. Lundberg, A., Muotka, T., Preda, E., Pulido-Velazquez, M., Schipper, P., 2011b. Ground-water dependent ecosystems. Part II. Ecosystem services and managemen in Europe under risk of climate change and land use intensification. Environ. Sci. Pol. 14 (7), 782-793.

Kokh, S.N., Shnyukov, Y.F., Sokol, E.V., Novikova, S.A., Kozmenko, O.A., Semenova, D.V., Rybak, E.N., 2015. Heavy carbon travertine related to methane generation: a case study of the Big

Tarkhan cold spring, Kerch Peninsula, Crimea. Sediment. Geol. 325, 26-40. Konhauser, K., 2007.

Introduction to Geomicrobiology. Blackwell Publishing (425 pp.). Kresic, N., 2010. Types and classifications of springs. In: Kresic, N., Stevanovic, Z. (Eds.)

Groundwater Hydrology of Springs. Butterworth-Heinemann, Boston, pp. 31-85. Kühn, G. 1940. Zur Ökologie und Biologie der Gewässer (Quellen und Abflüsse) des Wassergesprengs bei Wien. Arch. Hydrobiol. 36 (2), 157-262.

Levkov Z., Mitić-Kopanja D. \& Reichardt E. 2016. The diatom genus Gomphonema in the Republic of Macedonia. Diatoms of Europe 8 (H. Lange-Bertalot). (in press).

Lin, Y.-P., Singer, P.C., Aiken, G.R., 2005. Inhibition of calcite precipitation by natural organic material: kinetics, mechanism, and thermodynamics. Environ. Sci. Technol. 39 6420-6428.

Linhart, C., Schagerl, M., 2015. Seasonal succession of the travertine-forming desmid Oocardium stratum. Journal of Phycology (36 pp.).

Martin, P., Brunke, M., 2012. Faunal typology of lowland springs in Northern Germany. Freshw. Sci. 31, 542-562

Martin, P., Wischniowsky, L., 2014. Kalktuffquellen: FFH-Lebensraum ohne Charakterarten in der Limnofauna? Deutsche Gesellschaft für Limnologie (DGL). Erweiterte Zusammenfassungen der Jahrestagung 2013 (Potsdam). Hardegsen 2014, 72-76.

Martín-Algarra, A., Martín-Martín, M., Andreo, B., Julià, R., González-Gómez, C., 2003. Sedimentary patterns in perched spring travertines near Granada (Spain) as indicators of the paleohydrological and paleoclimatological evolution of a karst massif. Sediment. Geol. 161, 217-228.

Mastella, L., Rybak-Ostrowska, B., 2012. Tectonic control on tufa occurrences in the Pothole Synclinorium (Central Western Carpathians, southern Poland). Geol. Quart. 56 (4), 733-744.

Mayo, A.L., Peltier, S., Peterson, E.C., Payne, K., Holman, L.S., Tingey, D., Fogel, T., Black, B.L., Gibbs, T.D., 2003. Active and inactive groundwater flow systems: evidence from a stratified, mountainous terrain. GSA Bull. 115 (12), 1456-1472.

McKee, J.K., 2010. Formation and geomorphology of caves in calcareous tufts and implications for the study of the Taung fossil deposits. Trans. R. Soc. S. Afr. 48 (2)

307-322.

Meinzer, O.F., 1923. The occurrence of groundwater in the United States. Water Supply Paper 489. Government Printing Office, USGS, Washington D.C. (USA).

Merz, M.U.E., 1992. The biology of carbonate precipitation by cyanobacteria. Facies 26 , 81-102.

Merz-Preiß, M., Riding, R., 1999. Cyanobacterial tufa calcification in two freshwater streams: ambient environment, chemical thresholds and biologtical processes. Sedi-

ment. Geol. 126, 103-124.

Minissale, A., Kerrick, D.M., Magro, G., Murrell, M.T., Paladini, M., Rihs, S., Sturchio, N.C., Tassi, F., Vaselli, O., 2002. Geochemistry of Quaternary travertines in the region north of Rome (Italy): structural, hydrologic and paleoclimatic implications. Earth Planet. Sci. Lett. 203, 709-728.

Motyka, J., 1998. A conceptual model of hydraulic networks in carbonate rocks, illustrated by examples from Poland. Hydrogeol. J. 6, 469-482.

Netopil, R., 1971. Ke klasifikaci pramenu podle variability vydatnasti (The classification of water springs on the basis of the variability of yields). Czech. Sbornik-Hydrological

Conference. Papers. Stud. Geogr. 22, pp. 145-150.

Obenlüneschloss, J., 1991. Biologie und Ökologie von drei rezenten Süßwasser-Rivularien (Cyanobakterien) - Übertragbarkeit artspezifischer Verkalkungsstrukturen auf fossile Formen. Göttinger Arbeiten Geol. Paläont. 50, 1-86.

Ogata, K., Senger, K., Braathen, A., Tveranger, J., 2014. Fracture corridors as seal-bypass systems in siliciclastic reservoir-caprock successions: field-based insights from the Jurassic Entrada Formation (SE Utah, USA). J. Struct. Geol. 66, 162-187.
Olsson, J., Stipp, S.L.S., Gislason, S.R., 2014. Element scavenging by recently formed travertine deposits in the alkaline springs from the Oman Semail Ophiolite. Mineral. Mag. 78 (6), 1479-1490.

Omelon, C.R., Pollard, W.H., Marion, G.M., 2000. Seasonal formation of ikaite $\left(\mathrm{CaCO}_{3}\right.$ $6 \mathrm{H}_{2} \mathrm{O}$ ) in saline spring discharge at expedition fiord, Canadian high Arctic: assessing conditional constraints for natural crystal growth. Geochim. Cosmochim. Acta 65 (9), 1429-1437.

Pedley, H.M., 1990. Classification and environmental models of cool freshwater tufas. Sediment. Geol. 68, 143-154.

Pedley, M., 2009. Tufas and travertines of the Mediterranean region: a testing ground for freshwater carbonate concepts and developments. Sedimentology 56, 221-246. Pedley, M., Gonzáles Martín, J.A., Ordónez Delgado, S., García Del Cura, M.A., 2003. Sedimentology of Quaternary perched springline and paludal tufas: criteria for recognition, with examples from Guadalajara Province, Spain. Sedimentology $50,23-44$.

Pentecost, A., 1992. Carbonate chemistry of surface waters in a temperate Karst Region: the Southern Yorkshire Dales, UK. J. Hydrol. 139, 211-232.

Pentecost, A., 2005. Travertine. Springer, Berlin (445 pp.).

Pentecost, A., Jones, B., Renaut, R.W., 2003. What is a hot spring? Can. J. Earth Sci. 40 1443-1446.

Piccinini, L., De Nardo, M.T., Filippini, M., Segadelli, S., Vincenzi, V., Gargini, A., 2014. Hydrogeological protection of non-karstic fractured aquifers (in Italian).

Geoingegneria Ambientale e Mineraria 143 (3), 73-92

Plant, L.J., House, W.A., 2002. Precipitation of calcite in the presence of organic phosphate Colloids Surf. A Physicochem. Eng. Asp. 203, 143-153.

Powell, O., Silcock, J., Fensham, R.J., 2015. Oases to oblivion: the rapid demise of springs in the South-Eastern Great Artesian Basin of Australia. Groundwater 53, 171-178.

http://dx.doi.org/10.1111/gwat.12147.

Prado-Pérez, A.J. Hueras, A.D., Crespo, M.T., Martín Sánchez, A., Pérez Del Villar, L., 2013. Late Pleistocene and Holocene mid-latitude palaeoclimatic and palaeoenvironmenta reconstruction: an approach based on the isotopic record from a travertine formation in the guadix-baza basin, Spain. Geol. Mag. 150 (4), 602-625.

Priewisch, A., Crossey, L.J., Karlstrom, K.E., Polyak, V.J., Asmerom, Y., Nereson, A., Ricketts, J.W., 2014. U-series geochronology of large-volume Quaternary travertine deposits of the southeastern Colorado Plateau: evaluating episodicity and tectonic and paleohydrologic controls. Geosphere 10 (2), 401-423.

Ricketts, J.W., Karlstrom, K.E., Priewisch, A., Crossey, L.J., Polyak, V.J., Asmerom, Y., 2014 Quaternary extension in the Rio Grande rift at elevated strain rates recorded in travertine deposits, central New Mexico. Lithosphere 6 (1), 3-16.

Riding, R., 2000. Microbial carbonates: the geological record of calcified bacterial-algal mats and biofilms. Sedimentology 47 (1), 179-214.

Rogers, P., de Silva, R., Bhatia, R., 2002. Water in an economic good: how to use prices to promote equity, efficiency and sustainability. Water Policy 4, 1-17.

Rosell, J., Linares, R., 2001. Grandes deslizamientos en el frente de la lamina cabalgante del Montes (Sierra del Montsec, Prepirineo Central). Rev. Soc. Geol. Esp. 14 (3-4),

255-268.

Rott, E., Walser, L., Kegele, M., 2000. Ecophysiological aspects of macroalgal seasonality in a gravel stream in the Alps (River Isar, Austria). Verh. Int. Ver. Theor. Angew. Limnol. 27, 1622-1625.

Rott, E., Hotzy, R., Cantonati, M., Sanders, D., 2012. Calcification types of Oocardium stratum Nägeli and microhabitat conditions in springs of the Alps. Freshw. Sci. 31, 610-624.

Sanders, D., Rott, E., 2009. Contrasting styles of calcification by the micro-alga Oocardium stratum NAEGEL 1849 (zygnematophyceae) in two limestone-precipitating spring creeks of the Alps. Aust. J. Earth Sci. 102, 34-49.

Sanders, D., Ostermann, M., Brandner, R., Prager, C., 2010a. Meteoric lithification of catastrophic rockslide deposits: diagenesis and significance. Sediment. Geol. 223, 150

161.

Sanders, D., Ostermann, M., Kramers, J., 2010b. Meteoric diagenesis of Quaternary carbonate-rocky talus slope successions (Northern Calcareous Alps, Austria). Facies 56, 27-46

Sanders, D., Wertl, W., Rott, E., 2011. Spring-associated limestones of the Eastern Alps: overview of facies, deposystems, minerals and biota. Facies 57, 395-416.

Sant'Anna, L.G., Riccomini, C., Rodrigues-Francisco, B.H., Sial, A.N., Carvalho, M.D., Moura, C.A.V., 2004. The Paleocene travertine system of the Itaboraí basin, Southeastern Brazil. J. S. Am. Earth Sci. 18, 11-25.

Schagerl, M., Wukovits, J., 2014. Cultivation and inorganic carbon uptake of the rare desmid Oocardium stratum. Phycologia 53, 320-328.

Schleicher, J.M., 2011. Meteogenic travertine deposition through varied flow velocities: a model of the Fossil Creek travertine system in Verde, Arizona. Geological Society of America Abstracts with Programs 43 (5), 374.

Schröder, B., Howein, H., Gerecke, R., 2006. Quelltypen und Quellfauna. In: Gerecke, R., Franz, H. (Eds.), (2006): Quellen im Nationalpark Berchtesgaden. Lebensgemeinschaften als ndikatoren des Klimawandels. Nationalpark Berchtesgaden, Forschungsbericht 51, pp. 214-220.

Segadelli, S., Vescovi, P., Ogata, K., Chelli, A., Boschetti, T., Petrella, E., Toscani, L., Gargini, A. Celico, F., 2016d. A conceptual hydrogeological model of ophiolitic aquifers (serpentinized peridotite): The test example of Mt. Prinzera (northern Italy). Hydro-logical Processes (submitted)

Shi, Z., Shi, Z., Yin, G., Liang, J., 2014. Travertine deposits, deep thermal metamorphism and tectonic activity in the Longmenshan tectonic region, southwestern China. Tectonophysics 633, 156-163.

Shiraishi, F., Reimer, A., Bissett, A., de Beer, D., Arp, G., 2008. Microbial effects on biofilm calcification, ambient water chemistry and stable isotope records in a highly supersaturated setting (Westerhöfer Bach, Germany). Palaeogeogr. Palaeoclimatol. Palaeoecol. 262, 91-106. 
Søgaard, E.G., Aruna, R., Abraham-Peskir, J., Bender Koch, C., 2001. Conditions for biological precipitation of iron by Gallionella ferruginea in a slightly polluted groundwater. Appl. Geochem. 16, 1129-1137.

Spence, G.H., Redfern, J., Aguilera, R., Bevan, T.G., Cosgrove, J.W., Couples, G.D., Daniel, J.M., 2014. Advances in the study of fractured reservoirs. Geol. Soc. Lond. Spec. Publ. 374 http://dx.doi.org/10.1144/SP374.9.

Spitale, D., Leira, M., Angeli, N., Cantonati, M., 2012. Environmental classification of springs of the Italian Alps and its consistency across multiple taxonomic groups. Freshw. Sci. 31, 563-574.

Springer, A.E., Stevens, L., 2009. Spheres of discharge of springs. Hydrogeol. J. 17 (1), 83-93.

Thienemann, A., 1924. Die Gewässer Mitteleuropas - Eine hydrobiologische Charakteristik ihrer Haupttypen. Handbuch der Binnenfischerei Mitteleuropas Band 1, Lieferung. 1,

pp. 1-84.

Thienemann, A., 1934. Eine gesteinsbildende Chironomide (Lithotanytarsus emarginatus [Goetghebuer]. Z. Morphol. Okol. Tiere 28 (4), 480-496.

Tomaselli, M., Spitale D., Petraglia A. 2011. Phytosociological and ecological study of springs in Trentino (South-Eastern Alps, Italy). In: M. Cantonati, R. Gerecke, I. Jüttner and E.J. Cox (Guest Eds.), Springs: Neglected Key Habitats for Biodiversity Conserva-tion. J. Limnol. 70(Suppl.1): 23-53.

Turner, E.C., Jones, B., 2005. Microscopic calcite dendrites in cold-water tufa: implications for nucleation of micrite and cement. Sedimentology 52, 1043-1066.
Vaillant, F., Withers, P., 1993. Quelques Pericoma du groupe trifasciata (Diptera: Psychodidae, Psychodinae). Mitt. Schweiz. Entomol. Ges. 66 (1-2), 99-112.

Valero-Garcés, B.L., Arenas, C., Delgado-Huertas, A., 2001. Depositional environments of Quaternary lacustrine travertines and stromatolites from high-altitude Andean

lakes, northwestern Argentina. Can. J. Earth Sci. 38 (8), 1263-1283.

Vincenzi, V., Gargini, A., Goldscheider, N., Piccinini, L., 2014. Differential hydrogeological effects of draining tunnels through the northern Apennines, Italy. Rock Mech. Rock. Eng. 47 (3), 947-965.

Wallner, J., 1935. Diatomeen als Kalkbildner. Hedwigia 75: 137-145. Verlag C. Heinrich, Dresden.

Wehrli, M., Mitchell, E.A.D. Van der Knaap, W.O., Ammann, B., Tinner, W. 2010. Effects of climatic change and bog development on Holocene tufa formation in the Lorze Valley (Central Switzerland). The Holocene 20 (3), 325-336.

Zollhöfer, J.M., 1997. Quellen - die unbekannten Biotope im Schweizer Jura und Mittelland: erfassen, bewerten, schützen. Bristol-Schriftenreihe Band 6. BristolStiftung, Ruth und Herbert Uhl-Forschungsstelle für Natur- und Umweltschutz $153 \mathrm{pp}$.

Zentmyer, R., Myron, P.M., Newell, D.L., 2008. Travertine deposits from along the South Tibetan fault system near Nyalam. Tibet. Geol. Mag. 145 (6), 753-765. 